\title{
Pharmacist non-medical prescribing in primary care. A systematic review of views, opinions and attitudes
}

Article

Accepted Version

Mills, T., Patel, N. ORCID: https://orcid.org/0000-0002-86000663 and Ryan, K. (2021) Pharmacist non-medical prescribing in primary care. A systematic review of views, opinions and attitudes. International journal of clinical practice, 75 (3). e13827. ISSN 1368-5031 doi:

https://doi.org/10.1111/ijcp.13827 Available at https://centaur.reading.ac.uk/93801/

It is advisable to refer to the publisher's version if you intend to cite from the work. See Guidance on citing.

To link to this article DOI: http://dx.doi.org/10.1111/ijcp.13827

Publisher: Wiley

All outputs in CentAUR are protected by Intellectual Property Rights law, including copyright law. Copyright and IPR is retained by the creators or other copyright holders. Terms and conditions for use of this material are defined in the End User Agreement. 


\section{CentAUR}

Central Archive at the University of Reading

Reading's research outputs online 


\section{Pharmacist non-medical prescribing in primary care. A systematic review of views, opinions and attitudes.}

Timothy Mills, Nilesh Patel, Kath Ryan

Reading School of Pharmacy, University of Reading

\section{Keywords}

pharmacist prescribing, pharmacy, prescribing; non-medical, primary care, views; opinions; attitudes; sentiment.

\section{Summary}

\section{Background:}

Uptake of non-medical prescribing by pharmacists working in primary care has been slow. This is despite benefits such as quicker and more efficient access to medicines for patients, a reduction in doctor workload and enhanced professional satisfaction. This systematic review explores the views, opinions and attitudes of pharmacists and graduates towards nonmedical prescribing.

\section{Methods:}

Medline, ScienceDirect, Embase and the University of Reading Summon Service were searched to identify qualitative and mixed methods papers that examined the views, opinions and attitudes of pharmacists and graduates towards non-medical prescribing. Papers published between January 2003 and September 2017 were included. Studies were quality assessed using the CASP checklist and then analysed using thematic synthesis.

\section{Results:}

After 85 full text articles were assessed, a final 14 studies were eligible for inclusion. The included studies assessed pharmacists currently prescribing and other pharmacists and graduates with familiarity of non-medical prescribing. Thematic synthesis identified two themes: (1) practice environment, and (2) pharmacist's role. Non-medical prescribing was considered a natural extension to the role of a pharmacist despite difficulties in completing 
the required training. The ability to then prescribe was dependent on funding and access to medical records, time and support staff. Pharmacists experienced professional rivalry with both support and resistance from members of the primary care team. The provision of training was frequently referred to as unsatisfactory. Pharmacists were motivated to prescribe, deriving increased job satisfaction and sense of professionalism, however, they often felt under prepared for the reality of unsupervised practice. Furthermore, pharmacists reported a cautious approach with a fear of making errors frequently discussed.

\section{Conclusions:}

This review has identified themes and subsequent barriers and facilitators to non-medical prescribing. Many of the barriers are more perceived than real and are diminishing. Consideration of these will assist and advance pharmacist prescribing in primary care, leading to positive outcomes for both patient care and the pharmacy profession.

\section{Review Criteria}

- Medline, ScienceDirect, Embase and the University of Reading Summon Service were searched for studies on pharmacist non-medical prescribing in primary care from $1^{\text {st }}$ January 2003 until $1^{\text {st }}$ September 2017. Abstracts, and where appropriate, full papers were screened and reviewed by the first author (TM) to finalise the list of studies for this review.

\section{Message for the clinic}

- The practice environment where primary care pharmacists' work is largely a barrier to nonmedical prescribing. Examining this organisational environment and providing access to patient notes and enhancing training to support prescribing will make better use of pharmacists' skills, support other healthcare professionals and improve patient care.

- The pharmacists' role as a prescriber in primary care results in improved professional satisfaction, however many pharmacists report caution when prescribing, partly due to perceived inadequate training and support. 


\section{INTRODUCTION}

Non-medical prescribers (NMPs) are healthcare professionals, such as pharmacists and nurses, who have attained an advanced qualification in prescribing $(1,2)$. After subsequent registration with their relevant professional regulatory body, NMPs can prescribe medication to patients as part of their professional duties. This review looks at non-medical prescribing by pharmacists working in community pharmacy and general practice which in the UK is known as primary care and is the first point of contact for patients in the healthcare system. This is an expanding area of practice for the pharmacy profession, however currently there is a paucity of research here.

Non-medical prescribing has evolved primarily because there has been an increase in the need for healthcare that is team based and that offers quicker and more efficient access to medications (3). Research has demonstrated that NMPs can prescribe safely when clinically appropriate and positively improve patient access $(4,5)$. Patients report satisfaction, both in clinical terms and with pharmacist attributes $(6,7)$. Furthermore, NMPs have reported that having prescribing authority increases their job satisfaction and self-confidence, makes them more independent, and enables better use of their skills (8). Non-medical prescribing has developed internationally to reflect and adapt to different healthcare systems throughout the world (9). There are currently nearly a dozen countries, including the UK, Australia, New Zealand, Canada, USA, Ireland, Finland, Spain, Sweden and The Netherlands that have either fully or partially implemented non-medical prescribing. (10) The variation in implementation reflects differing frameworks, with many jurisdictions such as the Nordic countries restricting non-medical prescribing to nurses (11). Several other countries are currently considering pharmacist non-medical prescribing, amongst these are Nigeria, (12) Kenya (13) and Israel (14).

Pharmacists in the UK were first given supplementary prescribing rights in 2003. This prescribing model was dependent on a prior diagnosis by a doctor, or exceptionally, a dentist. Subsequently, with the patient's agreement, a voluntary partnership between the doctor and the NMP allowed the creation of an agreed clinical management plan. The NMP could then prescribe anything from this plan without further involvement from the doctor (15). This policy was not unique to the UK - for example, the American model of collaborative drug therapy is very similar (16). 
In May 2006, legislation was enacted in the UK that gave appropriately qualified pharmacists and nurses independent prescribing privileges. This gave them virtually the same independent prescribing rights as doctors and allows prescribing for any medical condition within the NMPs own level of experience and competence (17). NMPs in the UK are now a large and expanding workforce who play an increasing role in supporting the clinical commissioning programme for the modern National Health Service (NHS) (18). Nonmedical prescribing has thus progressed from its nascent stage and is now more prevalent. There is now increased awareness of non-medical prescribing amongst the healthcare profession (3) and increasing familiarity amongst patients in the UK (19). In 2017 the UK pharmacy regulator, the General Pharmaceutical Council (GPhC), stated there were 4,825 independent prescribers, 366 supplementary prescribers and a further 979 registered as both (20). This data means that about $11 \%$ of the total of 55,877 registered pharmacists are non-medical prescribers and there is scope for more pharmacists to become prescribers, suggesting that there are barriers to both training and practicing. Recently, $15.3 \%$ of Welsh pharmacist NMPs reported that they were limited in their prescribing practice by issues such as a lack of support from employers and managers, legislative restrictions, lack of a prescription pad and local formulary restrictions (21). There is a need to address the reasons for this apparent scarcity in uptake of prescribing rights and subsequent inconsistency in practice.

A Canadian study from 2015, described in detail why the pharmacy profession struggles sometimes with changes in practice. The authors argued that the personality traits of pharmacists do not enable them to take on active decision making in the care of patients but instead, lead them to seek others' approval for their suggestions. Risk factors in prescribing such as excessive workload, lack of communication, tiredness and patient complexity, remain significant for all prescribers, including pharmacists (22).

The purpose of this review is to look at pharmacist NMPs specifically in primary care, which is an expanding area for the pharmacy profession, and currently lacks research. The facilitators and barriers to non-medical prescribing are presented, followed by a discussion of how these fit into a wider understanding of pharmacists' views, opinions and attitudes to answer the research question. 


\section{METHODS}

This systematic review is reported in accordance with the Preferred Reporting Items for Systematic Reviews and Meta-Analyses (PRISMA) guidelines (23). The research question is “What are pharmacist's views, opinions and attitudes towards non-medical prescribing by primary care pharmacists?"

The results are reported in accordance with the ENTREQ and PRISMA statements (S1 and S2 Appendices) (23) (24)

\subsection{Data sources and search strategy}

Qualitative and mixed methods research studies were investigated. All original research articles were searched that had been published between $1^{\text {st }}$ January 2003 and $1^{\text {st }}$ September 2017. This covers the time from when legislation permitting prescribing by pharmacists was enacted in the UK.

An electronic search was conducted between $16^{\text {th }}$ October and $3^{\text {rd }}$ November 2017. Potentially relevant studies were identified by searching the following databases: Medline, ScienceDirect, Embase and the University of Reading Summon Service. Search terms were as follows: prescrib* and (pharmacist* or pharmacy * or nurse* or nonmedical* or nonmedical*) and (view* or opinion* or attitude* or acceptance*). An asterisk after a term means that all terms that begin with that root were included in the search.

Abstracts, and where appropriate, the full papers were screened and reviewed by the first author (TM) with selection if a paper met any of the inclusion criteria and none of the exclusion criteria. The reference list of each included study and relevant reviews were examined for potential studies and any additional relevant titles were included. In the event of any ambiguity, the paper was initially included, and the selected list of papers then reviewed by two further researchers (NP and KR) before the final list for the review was drawn up (Figure 1). Any disagreements were resolved by discussion. 


\subsubsection{Inclusion criteria}

Studies were included if they covered:

- supplementary and/or independent non-medical prescribing by pharmacists for patients in primary care only or in primary care and secondary care

- the views, opinions and attitudes of pharmacists or graduates towards or about nonmedical prescribing

- $\quad$ primary study designs published from January 2003 to September 2017

\subsubsection{Exclusion criteria}

Studies were excluded if they:

- did not include pharmacist NMPs or the views/opinions of pharmacists/graduates

- focussed solely on non-medical prescribing in a secondary or tertiary setting

- were outside of the date range

- were not in the English language

- related only to the teaching of non-medical prescribing skills or attributes

- looked solely at the supply of medicines via patient group directions

- $\quad$ were abstracts, conference proceedings, editorials or letters

\subsection{Data extraction and quality assessment}

The characteristics of the 14 studies are presented in Table 1. Due to the heterogeneous and primarily descriptive nature of the research identified, a CASP checklist was used to produce a score for each study (25). The assessment criteria extracted from CASP were: 1. Was there a clear statement of the aims of the research? 2. Is a qualitative methodology appropriate? 3. Was the research design appropriate to address the aims of the research? 4. Was the recruitment strategy appropriate to the aims of the research? 5 . Was the data collected in a way that addressed the research issue? 6 . Has the relationship between 
participants been adequately considered? 7. Have ethical issues been taken into consideration 8 . Was the data analysis sufficiently rigorous? 9. Is there a clear statement of findings? 10. How valuable is the research?

The studies were examined for all items on the CASP checklist. If the answer to the assessment criteria was yes, a score of 2 was given. If the answer to the assessment criteria was no, a score of 0 was given. If some papers met the assessment criteria partially or couldn't be assessed, a score of 1 was given. The data collected is presented in Table 2 .

\subsection{Analysis}

Qualitative analysis of all included studies was conducted using a thematic synthesis method described in Thomas and Harden (26). This approach was selected having been adopted previously for reviews concerning healthcare and allowing the research question to be addressed by developing analytical themes. Furthermore, this method allowed both the participants and the authors interpretations of views, opinions and attitudes to be captured. For papers that included both qualitative and quantitative data, only the qualitative components of the paper were analysed.

Initially studies were read with the main characteristics identified along with potential codes and themes. Line by line examination allowed coded concepts from one study to be generated by hand and then recognised as the same concept in another study, despite being expressed using non-identical words. As further codes were identified, new categories and themes were created. When no further codes were found, date analysis was considered to have been completed. Categories of individual concepts were then generated and reworded to create a higher order of themes consisting of seven categories, that were then grouped into three themes. This was discussed with all three members of the research team.

Table 1. Characteristics of included papers 


\begin{tabular}{|c|c|c|c|c|c|c|c|}
\hline $\begin{array}{l}\text { First } \\
\text { author } \\
\text { (year) } \\
\text { Country }\end{array}$ & Study aim & $\begin{array}{l}\text { Study } \\
\text { design }\end{array}$ & $\begin{array}{l}\text { Target } \\
\text { Group }\end{array}$ & $\begin{array}{l}\text { Participant } \\
\text { details }\end{array}$ & $\begin{array}{l}\text { Type of } \\
\text { analysis }\end{array}$ & $\begin{array}{l}\text { Results / } \\
\text { Outcomes }\end{array}$ & $\begin{array}{c}\text { How has this paper addressed } \\
\text { the research question }\end{array}$ \\
\hline $\begin{array}{l}\text { Bowskill } \\
\text { (2014) } \\
\text { England, } \\
\text { United } \\
\text { Kingdom } \\
\text { (27) }\end{array}$ & $\begin{array}{l}\text { Evaluate the uptake } \\
\text { and perceived usefulness } \\
\text { of a mentoring scheme } \\
\text { for two cohorts of NMP } \\
\text { students to discuss the } \\
\text { integration of } \\
\text { prescribing theory into } \\
\text { practice. } \\
\text { Independent Prescribing }\end{array}$ & $\begin{array}{l}\text { Mixed methods } \\
\text { survey and } \\
\text { semi-structured } \\
\text { interviews of } \\
\text { students and } \\
\text { their mentors }\end{array}$ & $\begin{array}{l}\text { Pharmacist } \\
\text { NMP students } \\
\text { Pharmacist } \\
\text { NMP mentors }\end{array}$ & $\begin{array}{l}63 \text { pharmacy NMP } \\
\text { students and } 63 \\
\text { pharmacist mentors } \\
\text { invited for } \\
\text { interview } \\
\text { Survey completed } \\
\text { by } 41(65.1 \%) \\
\text { students and } 36 \\
(57.1 \%) \text { pharmacist } \\
\text { mentors }\end{array}$ & $\begin{array}{l}\text { Content } \\
\text { analysis } \\
\text { Thematic } \\
\text { analysis }\end{array}$ & $\begin{array}{l}\text { Students found mentors } \\
\text { helpful, } \\
\text { but reported difficulty in } \\
\text { focusing on implementing } \\
\text { prescribing } \\
\text { Mentors benefited from } \\
\text { sharing / refreshing } \\
\text { academic knowledge } \\
\text { Mentoring scheme may be } \\
\text { better as post NMP support } \\
\text { resource when considering } \\
\text { prescribing practice }\end{array}$ & $\begin{array}{l}\text { The NMP pharmacy students reported enthusiasm in putting } \\
\text { their skills into practice and to prescribe. However, this } \\
\text { presented challenges which included difficulty in managing } \\
\text { competing demands on time and a perceived lack of support. } \\
\text { There were also academic challenges } \\
\text { Mentor support was valued, especially, in the early days. This } \\
\text { helped contextualise and implement prescribing into practice. } \\
\text { Being paired with a pharmacist prescriber was 'valuable' to } \\
\text { observe successful prescribing and to develop own } \\
\text { 'confidence' }\end{array}$ \\
\hline $\begin{array}{l}\text { Charrois } \\
(2012) \\
\text { Alberta, } \\
\text { Canada } \\
(28)\end{array}$ & $\begin{array}{l}\text { Examine specific } \\
\text { experiences of } \\
\text { pharmacists obtaining } \\
\text { prescriber designation } \\
\text { and help inform other } \\
\text { pharmacists considering } \\
\text { applying. } \\
\text { Supplementary } \\
\text { Prescribing }\end{array}$ & $\begin{array}{l}\text { Open-ended } \\
\text { questionnaire } \\
\text { regarding } \\
\text { experiences in } \\
\text { applying to } \\
\text { prescribe }\end{array}$ & $\begin{array}{l}\text { Pharmacist } \\
\text { NMPs }\end{array}$ & $\begin{array}{l}14 \text { pharmacists } \\
\text { prescribing in } \\
\text { primary invited to } \\
\text { participate } \\
\text { All } 14(100 \%) \\
\text { responded }\end{array}$ & $\begin{array}{l}\text { Content } \\
\text { analysis }\end{array}$ & $\begin{array}{l}\text { Unexpected factors were } \\
\text { experienced during the } \\
\text { application process, however } \\
\text { the outcome of obtaining } \\
\text { prescriber designation was } \\
\text { beneficial, professionally, } \\
\text { and with regard to patient } \\
\text { care }\end{array}$ & $\begin{array}{l}\text { Pharmacists described an ambivalent attitude towards } \\
\text { their prescribing training. On the one hand many were } \\
\text { motivated to prescribe in order to improve patient health } \\
\text { and collaborative relationships with other health care } \\
\text { professionals. Conversely, a lack of confidence in } \\
\text { knowledge and the realisation of potential harm to patients } \\
\text { was also discussed } \\
\text { Pharmacists expressed a desire to be at the 'leading edge' of } \\
\text { pharmacy practice and to validate some of the } \\
\text { responsibilities that were already being undertaken. } \\
\text { Scepticism and obstruction from other pharmacists was } \\
\text { also reported }\end{array}$ \\
\hline $\begin{array}{l}\text { Dawoud } \\
\text { (2011) } \\
\text { England, } \\
\text { United } \\
\text { Kingdom } \\
\text { (29) }\end{array}$ & $\begin{array}{l}\text { Investigate pharmacist } \\
\text { prescribers' views and } \\
\text { experiences of the early } \\
\text { stages of supplementary } \\
\text { prescribing } \\
\text { Implementation }\end{array}$ & $\begin{array}{l}\text { Qualitative, } \\
\text { longitudinal } \\
\text { study } \\
\text { consisting of } \\
\text { two semi- } \\
\text { structed } \\
\text { interviews with } \\
\text { pharmacist } \\
\text { prescribers at } 3 \\
\text { \& } 6 \text { months }\end{array}$ & $\begin{array}{l}\text { Pharmacist } \\
\text { NMPs }\end{array}$ & $\begin{array}{l}45 \text { pharmacist } \\
\text { prescribers invited. } \\
26(57.8 \%) \\
\text { responded and } 17 \\
\text { selected } \\
16 \text { pharmacists } \\
\text { subsequently } \\
\text { interviewed of } \\
\text { which } 5 \text { worked in }\end{array}$ & $\begin{array}{c}\text { Framework } \\
\text { analysis }\end{array}$ & $\begin{array}{l}\text { Some concern that } \\
\text { supplementary prescribing is } \\
\text { bureaucratic and limits } \\
\text { pharmacists' freedom. } \\
\text { Seen as a 'stepping stone' } \\
\text { for independent prescribing, } \\
\text { both models improve patient } \\
\text { care and support } \\
\text { pharmacists' integration and } \\
\text { job satisfaction }\end{array}$ & $\begin{array}{l}\text { There was much confidence and optimism about prescribing } \\
\text { reported. Pharmacists' commented on } \\
\text { professional respect with progressive support from } \\
\text { physicians } \\
\text { Some pharmacists supported the framework of the clinical } \\
\text { management plan as an aid to their prescribing } \\
\text { There was increased job satisfaction due to a sense of } \\
\text { achievement and desire to achieve best possible } \\
\text { outcomes, and significant time saving for patients and } \\
\text { doctors }\end{array}$ \\
\hline
\end{tabular}




\begin{tabular}{|c|c|c|c|c|c|c|c|}
\hline & & & & $\begin{array}{l}\text { primary care and } 11 \\
\text { in secondary care }\end{array}$ & & & $\begin{array}{l}\text { There was concern with a lack of funding and an } \\
\text { inadequate practice environment, including lack of clinical } \\
\text { space and delays in receiving prescription pads } \\
\text { Bureaucratic/restrictive supplementary prescribing resulted in } \\
\text { unnecessary paperwork - referred to as 'over documenting' } \\
\text { Pharmacists identified need for more training in physical } \\
\text { assessment skills }\end{array}$ \\
\hline $\begin{array}{l}\text { George et al } \\
\text { (2006) } \\
\text { Scotland, } \\
\text { United } \\
\text { Kingdom } \\
(30)\end{array}$ & $\begin{array}{l}\text { Investigate community } \\
\text { pharmacists' awareness, } \\
\text { views and attitudes } \\
\text { relating to independent } \\
\text { prescribing. } \\
\text { Perceptions of } \\
\text { competence and training } \\
\text { needs for management } \\
\text { of common conditions }\end{array}$ & $\begin{array}{l}\text { Pre-piloted } \\
\text { posted } \\
\text { questionnaire } \\
\text { to community } \\
\text { pharmacists }\end{array}$ & Pharmacists & $\begin{array}{l}\text { Questionnaire sent } \\
\text { to } 500 \text { primary care } \\
\text { pharmacists } \\
\\
217(43.4 \%) \\
\text { responded }\end{array}$ & $\begin{array}{l}\text { Principle } \\
\text { components } \\
\text { analysis }\end{array}$ & $\begin{array}{l}\text { Pharmacists perceived } \\
\text { themselves competent in } \\
\text { diagnosing and treating } \\
\text { minor conditions, however } \\
\text { clinical prescriber training } \\
\text { needed prior to pharmacist } \\
\text { registration as a prescriber } \\
\text { Improved consultation skills } \\
\text { and feedback to GP practices } \\
\text { identified as being important }\end{array}$ & $\begin{array}{l}\text { Most pharmacists stated they 'would be happy' to become } \\
\text { an independent prescriber and reported perceived } \\
\text { competence and confidence in diagnosing and treating } \\
\text { certain conditions } \\
\text { Pharmacists disagreed that 'GPs are unlikely to be in favour' } \\
\text { of independent prescribing by community pharmacists, } \\
\text { suggesting support } \\
\text { Gaining improved consultation skills and ability to } \\
\text { communicate prescribing to GP was regarded as important } \\
\text { More clinical training for selected conditions also } \\
\text { regarded as important before prescribing }\end{array}$ \\
\hline $\begin{array}{l}\text { Hoti et al } \\
(2010) \\
\text { Australia } \\
(31)\end{array}$ & $\begin{array}{l}\text { Evaluate the views of } \\
\text { Australian pharmacists } \\
\text { on pharmacist } \\
\text { supplementary } \\
\text { prescribing roles } \\
\text { Identify drivers and } \\
\text { barriers to } \\
\text { implementation. }\end{array}$ & $\begin{array}{l}\text { Self- } \\
\text { administered } \\
\text { questionnaires }\end{array}$ & Pharmacists & $\begin{array}{l}\text { Questionnaire sent } \\
\text { to } 2592 \text { pharmacists } \\
1049(40.5 \%) \\
\text { responded } \\
873 \text { pharmacists } \\
\text { worked in primary } \\
\text { care }\end{array}$ & $\begin{array}{l}\text { Factor } \\
\text { analysis }\end{array}$ & $\begin{array}{l}\text { High proportion of } \\
\text { pharmacists supported a } \\
\text { prescribing role for } \\
\text { pharmacists to expand } \\
\text { services } \\
\text { Preference for } \\
\text { supplementary prescribing }\end{array}$ & $\begin{array}{l}\text { Pharmacists supported a prescribing role to better use } \\
\text { their skills and ease the workload on general medical } \\
\text { practitioners. } \\
\text { This group of pharmacists generally preferred the } \\
\text { supplementary prescribing model over the independent } \\
\text { model, thus conceivably restricting potential of non- } \\
\text { medical prescribing } \\
\text { Inadequate training in disease diagnosis, patient } \\
\text { assessment and monitoring was perceived by pharmacists } \\
\text { Unsuitable prescribing environment such as inadequate } \\
\text { facilities within pharmacies and lack of time to prescribe } \\
\text { There is a risk of litigation }\end{array}$ \\
\hline
\end{tabular}




\begin{tabular}{|c|c|c|c|c|c|c|c|}
\hline $\begin{array}{l}\text { Hughes et al } \\
(2014) \\
\text { Alberta, } \\
\text { Canada } \\
(32)\end{array}$ & $\begin{array}{l}\text { Evaluation of what } \\
\text { prescribing means to } \\
\text { pharmacists in Alberta } \\
\text { and the application of } \\
\text { supplementary } \\
\text { prescribing in Pharmacy } \\
\text { Practice. }\end{array}$ & $\begin{array}{l}\text { Semi- } \\
\text { structured } \\
\text { telephone } \\
\text { interviews } \\
\text { using closed / } \\
\text { open-ended } \\
\text { questions }\end{array}$ & $\begin{array}{l}\text { Pharmacists } \\
\text { Pharmacist } \\
\text { NMPs }\end{array}$ & $\begin{array}{l}399 \text { pharmacists } \\
\text { contacted } \\
38(9.5 \%) \\
\text { participated in } \\
\text { interviews } \\
\\
28 \text { worked in } \\
\text { primary care }\end{array}$ & $\begin{array}{l}\text { Interpretive } \\
\text { description } \\
\text { approach }\end{array}$ & $\begin{array}{l}\text { Prescribing increased } \\
\text { responsibility of } \\
\text { pharmacists, augments their } \\
\text { role and has a wide breadth } \\
\text { of meaning, including } \\
\text { writing and extending } \\
\text { existing prescriptions }\end{array}$ & $\begin{array}{l}\text { Pharmacists reported: } \\
\text { Professional satisfaction in prescribing to improve patient } \\
\text { care and continue existing therapy } \\
\text { Extension to pharmacist's role by prescribing viewed } \\
\text { favourably } \\
\text { Risk associated with the increased responsibility when } \\
\text { writing a prescription, including concerns around follow } \\
\text { up and any necessary monitoring of drug therapy }\end{array}$ \\
\hline $\begin{array}{l}\text { Maddox et al } \\
\text { (2016) } \\
\text { England, } \\
\text { United } \\
\text { Kingdom } \\
\text { (33) }\end{array}$ & $\begin{array}{l}\text { Explore factors that } \\
\text { influence NMPs decision } \\
\text { to prescribe and take } \\
\text { responsibility for this. } \\
\text { Independent Prescribing }\end{array}$ & $\begin{array}{l}\text { Critical } \\
\text { incident } \\
\text { technique and } \\
\text { open questions } \\
\text { interviews } \\
\text { either face-to- } \\
\text { face or by } \\
\text { telephone. }\end{array}$ & $\begin{array}{l}\text { Pharmacist } \\
\text { NMPs } \\
\text { [Nurse NMPs] }\end{array}$ & $\begin{array}{l}15 \text { nurse prescribers } \\
5 \text { pharmacist } \\
\text { prescribers } \\
\text { all of which } \\
\text { working in primary } \\
\text { care }\end{array}$ & $\begin{array}{l}\text { Critical } \\
\text { incident } \\
\text { technique }\end{array}$ & $\begin{array}{l}\text { Perceptions of competency, } \\
\text { role and risk influenced } \\
\text { decision to prescribe. } \\
\text { Referral to a doctor was } \\
\text { identified as alternatives } \\
\text { Training and support to } \\
\text { overcome these would } \\
\text { enable professional } \\
\text { development and increase } \\
\text { competence }\end{array}$ & $\begin{array}{l}\text { This study assessed actual NMP by pharmacists } \\
\text { Comments included: } \\
\text { Working to guidelines facilitates acting within clear and } \\
\text { established boundaries } \\
\text { Pharmacists able to discuss prescribing with GP if doubts } \\
\text { arise. Also, valuable additional support from other } \\
\text { pharmacists contributed to increased competence } \\
\text { There was a perceived risk of making errors and caution } \\
\text { to ensure individual pharmacist wouldn't take } \\
\text { responsibility for prescribing that exceeds competency } \\
\text { Opportunities to expand prescribing practice restricted by } \\
\text { lack of training courses and material } \\
\text { Some perception (from non-prescribing colleagues) that } \\
\text { pharmacist NMP's role is to provide a prescription even if } \\
\text { patient not examined or outside competency or scope of } \\
\text { practice }\end{array}$ \\
\hline $\begin{array}{l}\text { Makowsky } \\
\text { et al } \\
\text { (2013) } \\
\text { Alberta, } \\
\text { Canada } \\
\text { (34) }\end{array}$ & $\begin{array}{l}\text { To explore the } \\
\text { facilitators and barriers } \\
\text { to the implementation of } \\
\text { pharmacist } \\
\text { supplementary } \\
\text { prescribing practice }\end{array}$ & $\begin{array}{l}\text { Semi- } \\
\text { structured } \\
\text { interviews } \\
\text { utilizing closed } \\
\text { and open-ended } \\
\text { questions over } \\
\text { the telephone. }\end{array}$ & $\begin{array}{l}\text { Pharmacist } \\
\text { NMPs }\end{array}$ & $\begin{array}{c}399 \text { pharmacists } \\
\text { contacted } \\
38(9.5 \%) \\
\text { interviewed for } \\
\text { study } \\
\text { Study authors state } \\
\text { ‘majority' worked } \\
\text { in primary care - } \\
\text { data reports } 28 \\
\text { worked in } \\
\text { community or } \\
\text { physician's office }\end{array}$ & $\begin{array}{l}\text { Interpretive } \\
\text { description } \\
\text { qualitative } \\
\text { philosophy }\end{array}$ & $\begin{array}{l}\text { Pharmacists' adoption of } \\
\text { prescribing was dependent } \\
\text { on innovation. Pharmacists } \\
\text { who have adopted, view } \\
\text { their prescribing as } \\
\text { legitimisation of previous } \\
\text { practice and advantageous to } \\
\text { daily tasks. Doctor } \\
\text { relationships impacted their } \\
\text { prescribing behaviour }\end{array}$ & $\begin{array}{l}\text { The reported facilitators and barriers are: } \\
\text { Prescribing had increased happiness, professional } \\
\text { satisfaction and image of pharmacists } \\
\text { Legitimization of previous practice such as switching } \\
\text { drugs due to shortage, or adapting dose } \\
\text { Support from wider healthcare team due to convenience } \\
\text { for physician and patient } \\
\text { No reimbursement for pharmacist's prescribing services } \\
\text { Time demands, perception that prescribing would lead to } \\
\text { less time working directly with patients and add to } \\
\text { workload due to documentation requirements and } \\
\text { communication with physician } \\
\text { Risk or liability associated with prescribing reduced } \\
\text { prescribing frequency, increased documentation and }\end{array}$ \\
\hline
\end{tabular}




\begin{tabular}{|c|c|c|c|c|c|c|c|}
\hline & & & & & & & $\begin{array}{l}\text { avoidance of 'high risk' medications that would not be } \\
\text { prescribed } \\
\text { Reluctance to prescribe if physician not supportive }\end{array}$ \\
\hline $\begin{array}{l}\text { McCann et } \\
\text { al } \\
(2011) \\
\text { Northern } \\
\text { Ireland } \\
\text { United } \\
\text { Kingdom } \\
\text { (35) }\end{array}$ & $\begin{array}{l}\text { Capture information on } \\
\text { pharmacist prescribing } \\
\text { in Northern Ireland. } \\
\text { Independent Prescribing }\end{array}$ & $\begin{array}{l}\text { Posted } \\
\text { structured self- } \\
\text { administered } \\
\text { questionnaire }\end{array}$ & $\begin{array}{l}\text { Pharmacist } \\
\text { NMPs }\end{array}$ & $\begin{array}{l}105 \text { pharmacists } \\
\text { invited. } 100 \\
\text { confirmed } \\
\text { eligibility } \\
76(76 \%) \text { responded } \\
33 \text { pharmacists } \\
\text { worked in primary } \\
\text { care }\end{array}$ & $\begin{array}{l}\text { Descriptive } \\
\text { analyses }\end{array}$ & $\begin{array}{l}\text { Benefits for patient care and } \\
\text { perception of the pharmacist. } \\
\text { Barriers include reluctance } \\
\text { to prescribe without a } \\
\text { diagnosis, lack of funding } \\
\text { and GP awareness. } \\
\text { Pharmacy prescribing has } \\
\text { yet to be routine and further } \\
\text { research is needed to provide } \\
\text { in-depth understanding and } \\
\text { examine patients' } \\
\text { experiences }\end{array}$ & $\begin{array}{l}\text { Key points: } \\
\text { Most pharmacists identified that prescribing reduced } \\
\text { time-delay for patients and increased compliance, } \\
\text { monitoring and safety } \\
\text { Prescribing increased job satisfaction, autonomy and } \\
\text { better utilized pharmacists' clinical skills } \\
\text { Professional respect with prescribing elevating status of } \\
\text { the pharmacist } \\
\text { Issues with the prescribing environment such as inability } \\
\text { to generate pharmacist prescriptions, need for shared } \\
\text { patient records and onerous paperwork } \\
\text { Inadequate funding and resources to support prescribing } \\
\text { Some GP opposition and lack of awareness of NMP's role } \\
\text { Cautious attitude of pharmacists }\end{array}$ \\
\hline $\begin{array}{l}\text { McIntosh et } \\
\text { al } \\
(2011) \\
\text { Scotland } \\
\text { United } \\
\text { Kingdom } \\
\text { (36) }\end{array}$ & $\begin{array}{l}\text { Investigate newly } \\
\text { registered pharmacist's } \\
\text { awareness of } \\
\text { independent prescribing } \\
\text { and views on potential } \\
\text { role as a prescriber }\end{array}$ & $\begin{array}{l}\text { Posted } \\
\text { questionnaire }\end{array}$ & Pharmacists & $\begin{array}{l}1658 \text { pharmacists } \\
\text { invited } \\
418(25.2 \%) \\
\text { responded } \\
\text { None currently } \\
\text { prescribing in any } \\
\text { setting }\end{array}$ & Not described & $\begin{array}{l}\text { Pharmacists report an } \\
\text { interest in prescribing } \\
\text { training, to improve patient } \\
\text { care and professional } \\
\text { standing. Issues around } \\
\text { clinical examination, patient } \\
\text { monitoring and medico-legal } \\
\text { aspects are reported }\end{array}$ & $\begin{array}{l}\text { Broad recognition of potential NMP role amongst newly } \\
\text { registered pharmacists, and almost all expressed an interest } \\
\text { in training as an independent prescriber. This would } \\
\text { enhance patient care and improve professional standing } \\
\text { Awareness of need to develop further clinical skills such } \\
\text { as examination, patient monitoring and medico-legal } \\
\text { aspects. Respondents expressed caution towards prescribing } \\
\text { role with few fully aware of legislation and scope }\end{array}$ \\
\hline $\begin{array}{l}\text { McIntosh et } \\
\text { al } \\
(2015) \\
\text { Scotland } \\
\text { United } \\
\text { Kingdom } \\
\text { (37) }\end{array}$ & $\begin{array}{l}\text { Explore the views and } \\
\text { reflections on pharmacist } \\
\text { prescribing of UK pre- } \\
\text { registration pharmacy } \\
\text { graduates } \\
\text { Supplementary and } \\
\text { Independent } \\
\text { Prescribing }\end{array}$ & $\begin{array}{l}\text { Qualitative } \\
\text { semi-structured } \\
\text { telephone } \\
\text { interviews }\end{array}$ & $\begin{array}{l}\text { Pharmacy } \\
\text { Pre-registration } \\
\text { graduates }\end{array}$ & $\begin{array}{l}118 \text { pharmacy } \\
\text { graduates invited } \\
12(10.2 \%) \text { newly } \\
\text { registered } \\
\text { pharmacists } \\
\text { interviewed }\end{array}$ & Not described & $\begin{array}{l}\text { Innovators in pharmacy } \\
\text { practice, pharmacists wanted } \\
\text { to train as prescribers, } \\
\text { acknowledging need for } \\
\text { initial development } \\
\text { Lack of organisational } \\
\text { strategy, self-confidence and } \\
\text { additional workload seen as } \\
\text { barriers } \\
\text { Value of interprofessional } \\
\text { relationships highlighted }\end{array}$ & $\begin{array}{l}\text { Most pharmacists hoped to train as prescribers, citing } \\
\text { professional development and job satisfaction as key } \\
\text { motivators } \\
\text { There is a need to build up confidence and experience due } \\
\text { to concerns around competence such as lack of diagnostic } \\
\text { skills. Frustration over lack of recognition of } \\
\text { undergraduate prescribing module and concerns around } \\
\text { deficiencies in organisational strategy, } \\
\text { lack of self-confidence and additional workload in } \\
\text { implementing prescribing }\end{array}$ \\
\hline
\end{tabular}




\begin{tabular}{|c|c|c|c|c|c|c|c|}
\hline & & & & & & & $\begin{array}{l}\text { Professional rivalry, dependent on speciality and how } \\
\text { comfortable doctors are to approve of prescribing }\end{array}$ \\
\hline $\begin{array}{l}\text { Stewart et al } \\
(2009) \\
\text { Scotland } \\
\text { United } \\
\text { Kingdom } \\
(38)\end{array}$ & $\begin{array}{l}\text { Explore perspectives } \\
\text { towards pharmacist } \\
\text { supplementary } \\
\text { prescribing }\end{array}$ & $\begin{array}{l}\text { Telephone } \\
\text { interviews }\end{array}$ & $\begin{array}{l}\text { Pharmacist } \\
\text { NMPs } \\
\text { [doctor \& } \\
\text { patient views } \\
\text { excluded] }\end{array}$ & $\begin{array}{c}18 \text { pharmacists } \\
\text { invited for } \\
\text { interview } \\
9(50 \%) \text { responded } \\
8 \text { worked in } \\
\text { primary care }\end{array}$ & $\begin{array}{l}\text { Qualitative } \\
\text { Case-study } \\
\text { analyses }\end{array}$ & $\begin{array}{l}\text { Benefits of pharmacist } \\
\text { prescribing for patients and } \\
\text { wider health care. Potential } \\
\text { lack of funding, inadequate } \\
\text { support networks and } \\
\text { continuing professional } \\
\text { development were identified } \\
\text { as potential barriers }\end{array}$ & $\begin{array}{l}\text { Motivating factors included opportunity to improve } \\
\text { patient care and complement the functions of other } \\
\text { healthcare team members which lead to enhanced job } \\
\text { satisfaction } \\
\text { Prescribing seen as natural extension to advisory role and } \\
\text { almost legalising current practice } \\
\text { Patients reflected positively on treatment, with quicker } \\
\text { access, better care and reduced doctor waiting times } \\
\text { despite some initial apprehension } \\
\text { Greater integration into healthcare team and improved } \\
\text { autonomy } \\
\text { Funding seen as a challenge with different arrangements } \\
\text { depending on practice setting } \\
\text { Lack of formal support network } \\
\text { Lack of appropriate continuing professional development } \\
\text { Concern about the competence of pharmacists }\end{array}$ \\
\hline $\begin{array}{l}\text { Tully et al } \\
\text { (2007) } \\
\text { England } \\
\text { United } \\
\text { Kingdom } \\
(39)\end{array}$ & $\begin{array}{l}\text { Investigate the views } \\
\text { and experiences of } \\
\text { pharmacists in England } \\
\text { before and after they } \\
\text { registered as } \\
\text { supplementary } \\
\text { prescribers }\end{array}$ & Interviews & $\begin{array}{l}\text { Pharmacist } \\
\text { NMP students } \\
\text { Pharmacist } \\
\text { NMPs }\end{array}$ & $\begin{array}{c}8 \text { pharmacists } \\
\text { recruited from } \\
\text { training courses } \\
\text { All interviewed } \\
\text { during training and } \\
\text { again after } \\
\text { completion } \\
1 \text { pharmacist } \\
\text { working in primary } \\
\text { care }\end{array}$ & $\begin{array}{l}\text { Qualitative } \\
\text { Interviews } \\
\text { With } \\
\text { Thematic } \\
\text { analyses }\end{array}$ & $\begin{array}{l}\text { Prescribing legitimises any } \\
\text { 'informal' practice with } \\
\text { legality and accountability } \\
\text { Procedural delays, and desire } \\
\text { to maintain non-prescribing } \\
\text { clinical services impacted } \\
\text { negatively }\end{array}$ & $\begin{array}{l}\text { Facilitators and barriers are identified, including: } \\
\text { Job satisfaction due to increased respect from the } \\
\text { multidisciplinary team, and a natural and important step } \\
\text { for the pharmacy profession } \\
\text { Validating responsibilities from previous 'informal' } \\
\text { prescribing } \\
\text { Bureaucratic/restrictive supplementary prescribing seen as } \\
\text { 'time consuming' and 'unwieldy' due to need for clinical } \\
\text { management plans } \\
\text { Considerable time obligation for prescribing course with } \\
\text { pharmacists describing personal sacrifice and 'crippling' time } \\
\text { commitment }\end{array}$ \\
\hline
\end{tabular}




\begin{tabular}{|c|c|c|c|c|c|c|c|}
\hline $\begin{array}{l}\text { Weiss et al } \\
\text { (2009) } \\
\text { England } \\
\text { United } \\
\text { Kingdom } \\
(40)\end{array}$ & $\begin{array}{l}\text { Investigates potential } \\
\text { threat to medical } \\
\text { dominance posed by } \\
\text { pharmacist independent } \\
\text { prescribers in the UK. } \\
\text { Explores the role of } \\
\text { prescribing as indicator } \\
\text { of professional power }\end{array}$ & $\begin{array}{l}\text { Semi- } \\
\text { structured } \\
\text { interviews and } \\
\text { case studies at } \\
\text { selected } \\
\text { prescribing } \\
\text { sites }\end{array}$ & $\begin{array}{l}\text { Pharmacist } \\
\text { NMPs }\end{array}$ & $\begin{array}{c}96 \text { pharmacists } \\
\text { contacted } \\
38(39 \%) \text { agreed to } \\
\text { take part in research } \\
\text { Authors selected } 23 \\
\text { pharmacists for } \\
\text { interview } \\
13 \text { pharmacists } \\
\text { worked in primary } \\
\text { care }\end{array}$ & $\begin{array}{l}\text { Qualitative } \\
\text { Interviews } \\
\text { Case studies }\end{array}$ & $\begin{array}{l}\text { Pharmacist 'legitimacy' } \\
\text { enhanced by prescribing } \\
\text { role. Personal limitations } \\
\text { with regard to range of clinic } \\
\text { areas or processes } \\
\text { Medical prescribing has } \\
\text { retained high status, often by } \\
\text { 'overseer' role for all } \\
\text { prescribing and controlling } \\
\text { knowledge base relevant for } \\
\text { prescribing practice. }\end{array}$ & $\begin{array}{l}\text { This study evaluates how pharmacist NMP fits into the } \\
\text { established norm where prescribing is conducted } \\
\text { exclusively by medical doctors } \\
\text { It highlights professional self-worth and associated status } \\
\text { for pharmacists, identifies that some pharmacists felt their } \\
\text { singular expertise on medicines would improve safety and } \\
\text { access of medicines for patients } \\
\text { It is reported that there is a cautious attitude with some } \\
\text { pharmacists seeing themselves as subordinates within a } \\
\text { medically dominated hierarchy. Additionally } \\
\text { self-limitation and constraint on prescribing due to } \\
\text { competence, especially with clinical examinations and initial } \\
\text { diagnostic decisions } \\
\text { Discussion that there is a perception that pharmacists won't } \\
\text { want to clinically examine patients and there is unease from } \\
\text { doctors with pharmacist NMP }\end{array}$ \\
\hline
\end{tabular}


Table 2. Assessment of included studies

\begin{tabular}{|c|c|c|c|c|c|c|c|c|c|c|c|}
\hline $\begin{array}{l}\text { Primary } \\
\text { Author } \\
\text { (year) }\end{array}$ & $\begin{array}{l}\text { Clear Statement } \\
\text { of aims? }\end{array}$ & $\begin{array}{l}\text { Appropriate } \\
\text { qualitative } \\
\text { methodology? }\end{array}$ & $\begin{array}{l}\text { Research design } \\
\text { appropriate } \\
\text { for aims? }\end{array}$ & $\begin{array}{l}\text { Recruitment } \\
\text { strategy } \\
\text { appropriate for } \\
\text { aims? }\end{array}$ & $\begin{array}{l}\text { Data collected } \\
\text { In a way that } \\
\text { addresses } \\
\text { research question? }\end{array}$ & $\begin{array}{l}\text { Relationship } \\
\text { Between researcher } \\
\text { and participants } \\
\text { Considered }\end{array}$ & $\begin{array}{l}\text { Ethical Issues } \\
\text { Considered? }\end{array}$ & $\begin{array}{l}\text { Sufficiently } \\
\text { rigorous } \\
\text { Data analysis? }\end{array}$ & $\begin{array}{l}\text { Clear statement } \\
\text { Of findings? }\end{array}$ & $\begin{array}{l}\text { Is research } \\
\text { valuable? }\end{array}$ & $\begin{array}{l}\text { Overall } \\
\text { Score }\end{array}$ \\
\hline $\begin{array}{l}\text { Bowskill } \\
\text { (2006) }\end{array}$ & $\begin{array}{l}\text { Yes } \\
2\end{array}$ & $\begin{array}{l}\text { Yes } \\
2\end{array}$ & $\begin{array}{l}\text { Yes } \\
2\end{array}$ & $\begin{array}{l}\text { Yes } \\
2\end{array}$ & $\begin{array}{l}\text { Yes } \\
2\end{array}$ & $\begin{array}{l}\text { Yes } \\
2\end{array}$ & $\begin{array}{l}\text { Yes } \\
2\end{array}$ & $\begin{array}{l}\text { Yes } \\
2\end{array}$ & $\begin{array}{l}\text { Yes } \\
2\end{array}$ & $\begin{array}{l}\text { Partially } \\
1\end{array}$ & 19 \\
\hline $\begin{array}{l}\text { Charrois } \\
\text { (2012) }\end{array}$ & $\begin{array}{l}\text { Yes } \\
2\end{array}$ & $\begin{array}{l}\text { Yes } \\
2\end{array}$ & $\begin{array}{l}\text { Yes } \\
2\end{array}$ & $\begin{array}{l}\text { Yes } \\
2\end{array}$ & $\begin{array}{l}\text { Yes } \\
2\end{array}$ & $\begin{array}{l}\text { Yes } \\
2\end{array}$ & $\begin{array}{l}\text { Partially } \\
1\end{array}$ & $\begin{array}{l}\text { Partially } \\
1\end{array}$ & $\begin{array}{l}\text { Yes } \\
2\end{array}$ & $\begin{array}{l}\text { Yes } \\
2\end{array}$ & 18 \\
\hline $\begin{array}{l}\text { George } \\
(2006)\end{array}$ & $\begin{array}{l}\text { Yes } \\
2\end{array}$ & $\begin{array}{l}\text { Yes } \\
2\end{array}$ & $\begin{array}{l}\text { Yes } \\
2\end{array}$ & $\begin{array}{l}\text { Yes } \\
2\end{array}$ & $\begin{array}{l}\text { Yes } \\
2\end{array}$ & $\begin{array}{l}\text { Yes } \\
2\end{array}$ & $\begin{array}{l}\text { Yes } \\
2\end{array}$ & $\begin{array}{l}\text { Yes } \\
2\end{array}$ & $\begin{array}{l}\text { Yes } \\
2\end{array}$ & $\begin{array}{l}\text { Yes } \\
2\end{array}$ & 20 \\
\hline $\begin{array}{l}\text { Hoti } \\
(2010)\end{array}$ & $\begin{array}{l}\text { Yes } \\
2\end{array}$ & $\begin{array}{l}\text { Yes } \\
2\end{array}$ & $\begin{array}{l}\text { Yes } \\
2\end{array}$ & $\begin{array}{l}\text { Yes } \\
2\end{array}$ & $\begin{array}{l}\text { Yes } \\
2\end{array}$ & $\begin{array}{l}\text { Yes } \\
2\end{array}$ & $\begin{array}{l}\text { Yes } \\
2\end{array}$ & $\begin{array}{l}\text { Yes } \\
2\end{array}$ & $\begin{array}{l}\text { Yes } \\
2\end{array}$ & $\begin{array}{l}\text { Yes } \\
2\end{array}$ & 20 \\
\hline $\begin{array}{l}\text { Hughes } \\
\text { (2014) }\end{array}$ & $\begin{array}{l}\text { Yes } \\
2\end{array}$ & $\begin{array}{l}\text { Yes } \\
2\end{array}$ & $\begin{array}{l}\text { Yes } \\
2\end{array}$ & $\begin{array}{l}\text { Partially } \\
1\end{array}$ & $\begin{array}{l}\text { Yes } \\
2\end{array}$ & $\begin{array}{l}\text { Yes } \\
2\end{array}$ & $\begin{array}{l}\text { Yes } \\
2\end{array}$ & $\begin{array}{l}\text { Yes } \\
2\end{array}$ & $\begin{array}{l}\text { Partially } \\
1\end{array}$ & $\begin{array}{l}\text { Partially } \\
1\end{array}$ & 17 \\
\hline $\begin{array}{l}\text { Maddox } \\
(2016)\end{array}$ & $\begin{array}{l}\text { Yes } \\
2\end{array}$ & $\begin{array}{l}\text { Yes } \\
2\end{array}$ & $\begin{array}{l}\text { Yes } \\
2\end{array}$ & $\begin{array}{l}\text { Yes } \\
2\end{array}$ & $\begin{array}{l}\text { Yes } \\
2\end{array}$ & $\begin{array}{l}\text { Yes } \\
2\end{array}$ & $\begin{array}{l}\text { Yes } \\
2\end{array}$ & $\begin{array}{l}\text { Yes } \\
2\end{array}$ & $\begin{array}{l}\text { Yes } \\
2\end{array}$ & $\begin{array}{l}\text { Partially } \\
1\end{array}$ & 19 \\
\hline $\begin{array}{l}\text { Makowsky } \\
(2013)\end{array}$ & $\begin{array}{l}\text { Yes } \\
2\end{array}$ & $\begin{array}{l}\text { Yes } \\
2\end{array}$ & $\begin{array}{l}\text { Yes } \\
2\end{array}$ & $\begin{array}{l}\text { Yes } \\
2\end{array}$ & $\begin{array}{l}\text { Yes } \\
2\end{array}$ & $\begin{array}{l}\text { Yes } \\
2\end{array}$ & $\begin{array}{l}\text { Yes } \\
2\end{array}$ & $\begin{array}{l}\text { Yes } \\
2\end{array}$ & $\begin{array}{l}\text { Partially } \\
1\end{array}$ & $\begin{array}{l}\text { Partially } \\
1\end{array}$ & 18 \\
\hline $\begin{array}{l}\text { McCann } \\
\text { (2011) }\end{array}$ & $\begin{array}{l}\text { Yes } \\
2\end{array}$ & $\begin{array}{l}\text { Yes } \\
2\end{array}$ & $\begin{array}{l}\text { Yes } \\
2\end{array}$ & $\begin{array}{l}\text { Yes } \\
2\end{array}$ & $\begin{array}{l}\text { Yes } \\
2\end{array}$ & $\begin{array}{l}\text { Yes } \\
2\end{array}$ & $\begin{array}{l}\text { Yes } \\
2\end{array}$ & $\begin{array}{l}\text { Yes } \\
2\end{array}$ & $\begin{array}{l}\text { Yes } \\
2\end{array}$ & $\begin{array}{l}\text { Yes } \\
2\end{array}$ & 20 \\
\hline $\begin{array}{l}\text { McIntosh } \\
\text { (2011) }\end{array}$ & $\begin{array}{l}\text { Yes } \\
2\end{array}$ & $\begin{array}{l}\text { Yes } \\
2\end{array}$ & $\begin{array}{l}\text { Yes } \\
2\end{array}$ & $\begin{array}{l}\text { Partially } \\
1\end{array}$ & $\begin{array}{l}\text { Partially } \\
1\end{array}$ & $\begin{array}{l}\text { Yes } \\
2\end{array}$ & $\begin{array}{l}\text { Yes } \\
2\end{array}$ & $\begin{array}{l}\text { No } \\
0\end{array}$ & $\begin{array}{l}\text { Partially } \\
1\end{array}$ & $\begin{array}{l}\text { Partially } \\
1\end{array}$ & 14 \\
\hline $\begin{array}{l}\text { McIntosh } \\
\text { (2015) }\end{array}$ & $\begin{array}{l}\text { Yes } \\
2\end{array}$ & $\begin{array}{l}\text { Yes } \\
2\end{array}$ & $\begin{array}{l}\text { Yes } \\
2\end{array}$ & $\begin{array}{l}\text { Yes } \\
2\end{array}$ & $\begin{array}{l}\text { Yes } \\
2\end{array}$ & $\begin{array}{l}\text { Yes } \\
2\end{array}$ & $\begin{array}{l}\text { Yes } \\
2\end{array}$ & $\begin{array}{l}\text { Yes } \\
2\end{array}$ & $\begin{array}{l}\text { Yes } \\
2\end{array}$ & $\begin{array}{l}\text { Yes } \\
2\end{array}$ & 20 \\
\hline $\begin{array}{l}\text { Stewart } \\
(2009)\end{array}$ & $\begin{array}{l}\text { Yes } \\
2\end{array}$ & $\begin{array}{l}\text { Yes } \\
2\end{array}$ & $\begin{array}{l}\text { Yes } \\
2\end{array}$ & $\begin{array}{l}\text { Yes } \\
2\end{array}$ & $\begin{array}{l}\text { Yes } \\
2\end{array}$ & $\begin{array}{l}\text { Yes } \\
2\end{array}$ & $\begin{array}{l}\text { Yes } \\
2\end{array}$ & $\begin{array}{l}\text { Yes } \\
2\end{array}$ & $\begin{array}{l}\text { Yes } \\
2\end{array}$ & $\begin{array}{l}\text { Yes } \\
2\end{array}$ & 20 \\
\hline $\begin{array}{l}\text { Tully } \\
\text { (2017) }\end{array}$ & $\begin{array}{l}\text { Yes } \\
2\end{array}$ & $\begin{array}{l}\text { Yes } \\
2\end{array}$ & $\begin{array}{l}\text { Yes } \\
2\end{array}$ & $\begin{array}{l}\text { Partially } \\
1\end{array}$ & $\begin{array}{l}\text { Yes } \\
2\end{array}$ & $\begin{array}{l}\text { Yes } \\
2\end{array}$ & $\begin{array}{l}\text { Yes } \\
2\end{array}$ & $\begin{array}{l}\text { Yes } \\
2\end{array}$ & $\begin{array}{l}\text { Yes } \\
2\end{array}$ & $\begin{array}{l}\text { Partially } \\
1\end{array}$ & 18 \\
\hline $\begin{array}{l}\text { Weiss } \\
\text { (2009) }\end{array}$ & $\begin{array}{l}\text { Yes } \\
2\end{array}$ & $\begin{array}{l}\text { Yes } \\
2\end{array}$ & $\begin{array}{l}\text { Yes } \\
2\end{array}$ & $\begin{array}{l}\text { Yes } \\
2\end{array}$ & $\begin{array}{l}\text { Yes } \\
2\end{array}$ & $\begin{array}{l}\text { Yes } \\
2\end{array}$ & $\begin{array}{l}\text { Yes } \\
2\end{array}$ & $\begin{array}{l}\text { Yes } \\
2\end{array}$ & $\begin{array}{l}\text { Yes } \\
2\end{array}$ & $\begin{array}{l}\text { Yes } \\
2\end{array}$ & 20 \\
\hline
\end{tabular}




\section{RESULTS}

The database search identified 2696 studies. Following the exclusion of 1483 duplicates and 1128 from review of the title and abstract, 85 full text studies were reviewed. After final exclusions, 14 studies met the inclusion criteria and were included in the analysis. (Figure 1)

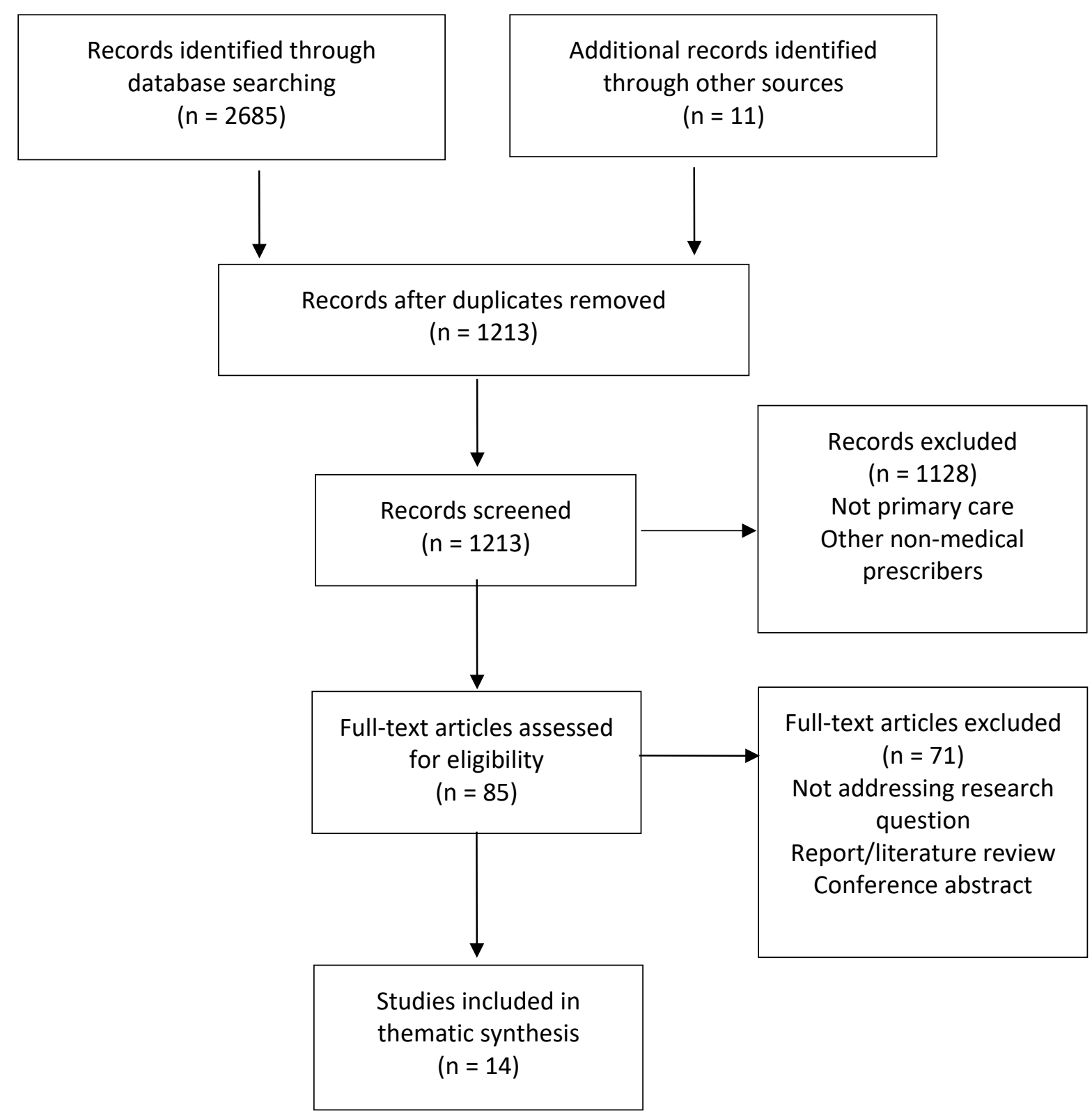

Figure 1. PRISMA flow diagram

All studies used qualitative methods, although several included a mixed methodology with quantitative data being collected and analysed concurrently. The individual study 
characteristics are presented in Table 1. The majority of studies were found to be of good quality with a score of $17 / 20$ or higher (Table 2). Considering the limited number of available studies and the possibility of useful findings in lesser quality papers, the paper judged to be of moderate quality (14/20) was also included. Identified deficiencies in some papers included insufficient description of the methods of analysis and an absence of appropriate evidence of reflexivity, which did not permit informed judgement of potential biases and credibility of findings.

Thematic analysis identified two themes, (1) Practice Environment and (2) Pharmacist's Role (figure 2).

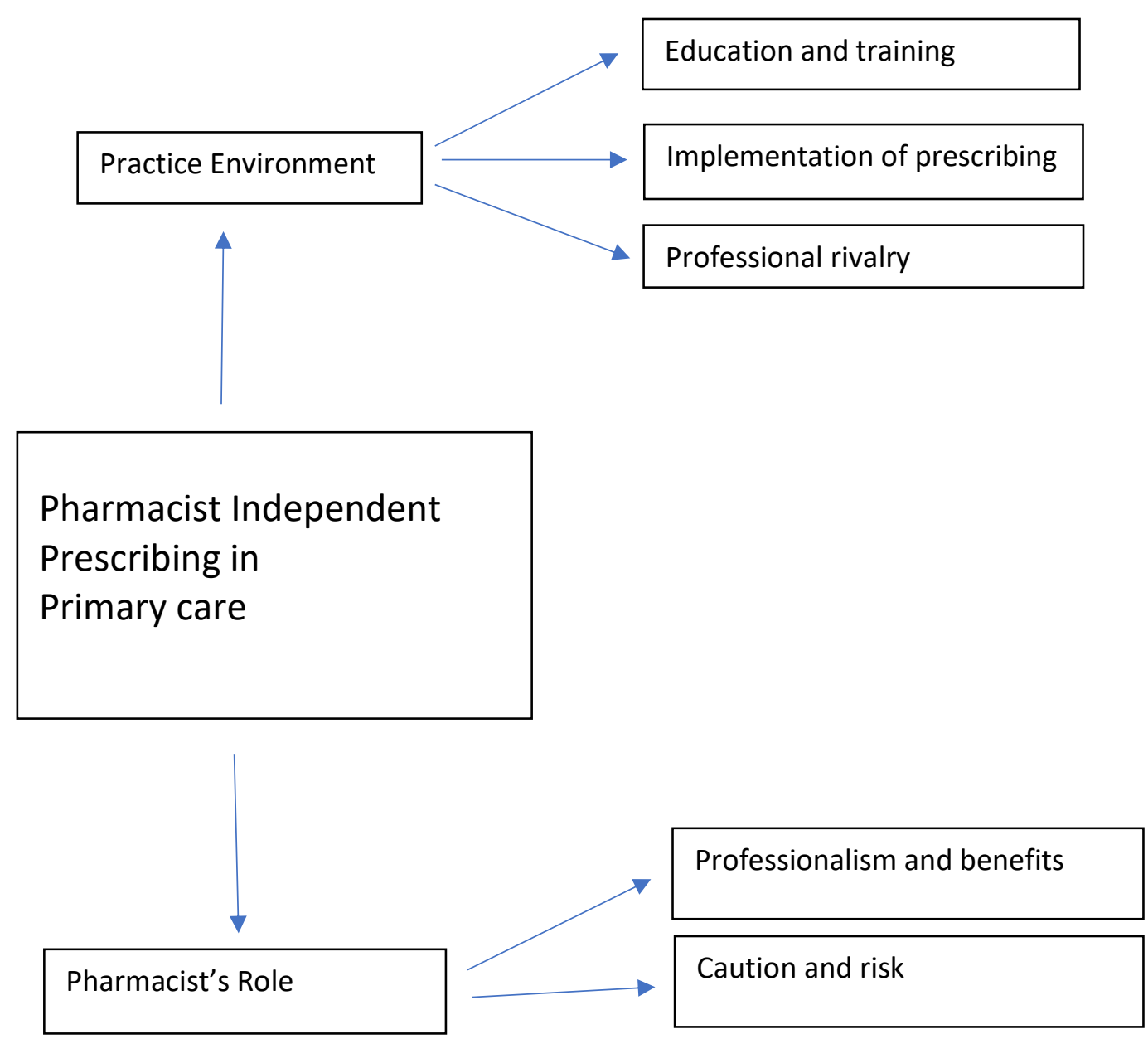

Figure 2: Themes and their associated sub-themes 
These themes and sub-themes are presented with illustrative quotes from the study author(s). Citations from individual pharmacist participants have quotation marks and are printed in italics.

\section{Practice Environment}

Most pharmacists undertook a prescribing qualification alongside existing work in primary care. After qualification, pharmacists found prescribing required greater assessment of the patient and more detailed documentation than dispensing. Numerous factors, largely beyond the control of individual pharmacists facilitated or constrained prescribing. These factors made up the practice environment where prescribing occurs. They included issues such as funding, time, support and reciprocal involvement with doctors. A lack of support, or mentoring, was also reported by pharmacists.

\section{Education and training}

Pharmacists reported challenges when returning to study to undertake a qualification in prescribing. Study was often considered arduous and was usually completed alongside existing duties, with pharmacists finding it difficult to balance work, study and leisure time.

Their concerns about completing the course and managing competing demands on their time influenced their uptake [of the prescribing qualification]. (27)

All described considerable personal sacrifice, both emotionally and in the 'crippling' time commitment that they gave to the course. (39)

In addition, the provision of training during the prescribing course and subsequent availability of further training was frequently referred to as unsatisfactory and lacking in areas such as diagnosis and consultation skills. In some cases, this was thought to hinder the ability to prescribe. 
Respondents wanted further education and training in relation to diagnosis of the conditions studied and drugs used for treating those conditions. Gaining communication and consultation skills were also regarded to be important. (30)

Inadequate training in patient assessment, diagnosis and monitoring were the strongest barriers to expanded pharmacist prescribing. (31)

Two pharmacist non-medical prescribers felt that opportunities to expand their prescribing practice were restricted by the lack of training courses and material targeted at the appropriate level for pharmacist prescribers. (33)

\section{Implementation of prescribing}

Many pharmacists in the studies reported working in a community pharmacy setting rather than in other primary care settings, such as doctor-led general practice. Difficulties in making provision for prescribing in community pharmacy, however, hindered and frustrated pharmacists. They reported difficulties in finding time to prescribe amongst their other duties such as supervising dispensing of medication, and difficulties in balancing their overall workload. Many pharmacists described their frustration at not being able to use their prescribing qualification.

"I have seen no evidence that supplementary or independent prescribing will be implemented in community pharmacy. I believe I will never use my qualification and that it was 'mis-sold' to me." (35)

When prescribing had become a reality, they would have to lose some of the traditional roles of pharmacists to gain the time to act as prescribers. (39)

One pharmacist did not obtain [a prescribing qualification] as she felt she would have less time for working with patients. (34)

For other pharmacists who used their qualification and prescribed, their ability was often restricted by a lack of resources, planning and strategic vision from both professional and leadership bodies, such as the Royal Pharmaceutical Society (RPS) and the NHS in the UK. 
These restrictions were reported as, an inability to access medical records, an absence of funding, unavailability of resources such as prescription pads and a lack of time to prescribe.

"Funding and access to clinical notes are the main barriers. With an increasing workload in my dispensary ... it does not pay me." (35)

"I feel that pharmacy independent prescribing can only take place in a primary care setting, within GP practices. This is because we [community pharmacists] have no access to patient history and notes otherwise. This makes prescribing from elsewhere more difficult and possibly less effective." (35)

When asked about resources needed to prescribe, pharmacists most commonly mentioned time and staffing, access to lab values through the provincial electronic health record. (34)

In contrast, some pharmacists declared that prescribing was a natural extension to their practice and legitimised what they had been doing previously.

"Before we had prescribing, we did continuity as well. We just provided the medication and got the OK from the doctor the next day." (34)

"Within the medical practice we are almost doing a prescribing role anyway, going through the motions almost, so this was just a natural step to do the qualification." (38)

Many pharmacists in primary care felt support abruptly ended after training had been completed, which led to feelings of isolation.

One key issue was that most pharmacists felt a lack of any formal support networks and often relied informally on other trained colleagues for advice (38)

Professional rivalry

Some studies documented that pharmacist prescribing had led to professional rivalry, chiefly from doctors, imbued in traditional roles and hierarchies. A negative attitude from doctors and other pharmacists often discouraged pharmacists from prescribing. 
"I feel that GPs are not ready to hand over any of their prescribing yet to pharmacists. Many GPs feel that the idea of pharmacist prescribing is very contentious and feel there is a conflict of interest between pharmacist prescribing and dispensing." (35)

"I know that doctors are very worried about their loss of power, if you like, letting go of prescribing is quite hard for doctors." (40)

One pharmacist relayed a story where she "had pharmacists' phone her to say it's not fair that she is doing this prescribing". She also had pharmacists refuse to accept prescriptions from her. (28)

Contrary to this some pharmacists, especially those from the United Kingdom, reported doctors who supported them to use their prescribing skills.

Overall pharmacists felt their doctors would support them if they intended to extend their role to independent prescribing. (38)

"I feel that they [doctors] treat us more like equals now." (40)

\section{Pharmacist's role}

Pharmacists identified benefits from non-medical prescribing in primary care. A natural fear and hesitation in taking greater responsibility for the care of patients was also reported, with pharmacists prescribing in line with their competency and experience, which was often lacking in the early stages post qualification.

\section{Professionalism and benefits}

Pharmacists reported that prescribing was beneficial to patients, doctors and the wider healthcare community. Evidence that pharmacists are motivated to prescribe is reported throughout the included studies. Researchers identified enhanced job satisfaction, professionalism and an impetus to prescribe. Pharmacists thought prescribing provided better access to care for patients. 
Several factors influenced their decision to apply to [prescribe]. These included being at the leading edge of pharmacy practice and change. (28)

Prescribing had increased their sense of professionalism, the image of the professional healthcare provider and their own job satisfaction and happiness. (34)

Pharmacists noted benefits of their enhanced job satisfaction, responsibility and autonomy. (38)

Most pharmacists agreed or strongly agreed that pharmacist prescribing reduced the time-delay for patients between dose adjustments, increased continuity of care, increased patient compliance/adherence, increased monitoring of patient's drug therapy and improved patient safety. (35)

\section{Caution and risk}

Pharmacists reported a cautious approach when prescribing due to the fear of making an error. They expressed concern that patient care could be negatively impacted if their assessment and clinical decisions were inadequate.

Pharmacists related concerns over the risk or liability associated with prescribing. Overall, most pharmacists believed that [prescribing] had increased risk. (34)

One pharmacist noted that realising she could actually harm a patient with her decisions was a hard concept for her to process. (28)

Most [non-medical prescribers] adopted a cautious approach to taking responsibility for issuing a prescription, "If I am in any whatsoever doubt then I just buzz through to the GP." (33)

\section{DISCUSSION}

This is the first systematic review looking solely at primary care pharmacist's views, opinions and attitudes towards non-medical prescribing. The included studies originated from three 
countries - the UK, Canada and Australia. Data was synthesised from a wide range of primary qualitative research literature and identified two themes, each containing subthemes. These two themes were practice environment and pharmacist's role.

Requirements for pharmacists to practice as a non-medical prescriber differ depending on the country concerned. In order to provide context in examining any differences in the qualitative data from pharmacists in different jurisdictions, these contrasting requirements are briefly discussed. To qualify as a prescriber in Great Britain, pharmacists must complete a GPhC accredited programme. These prescribing programmes are part time, typically run over a period of 6-9 months and are often delivered through a combination of face-to-face teaching sessions and self-directed study. Concurrent to this, pharmacists must complete at least 12 days of learning in a practice environment whilst being mentored by a medical practitioner (41). In Canada, pharmacists can apply to prescribe in nearly every province in the country (42). In the province of Alberta, for example, pharmacists on the clinical register must complete an orientation programme delivered by the Alberta College of Pharmacists and then apply for additional prescribing rights by completing a detailed application that is assessed by peers. This application must meet criteria which includes, at least one year fulltime experience in direct patient care, strong collaborative relationships with other health professionals and support in practice, such as access to information, communication and documentation (43). In Australia, prescribing rights for pharmacists have yet to be implemented (44). Currently community pharmacists can supply ‘Pharmacist Only Medicines', and in recent years, a range of prescription medicines have been down scheduled to this category, including medicines for emergency contraception, chloramphenicol eye drops and some proton pump inhibitors (45). The results in this review reflect the qualitative data derived from all 14 of the included studies. Each sub-theme in this review was identified from more than one study, and all included data from different geographical locations. This demonstrates that pharmacists perceived similar barriers and facilitators to non-medical prescribing irrespective of the country that they and the study authors were familiar with. The findings of this study have implications internationally, particularly in countries in the infancy of setting up pharmacist NMP. 
In the practice environment theme, education and training were cited frequently with many pharmacists reporting deficiencies here. Inadequate training was often reported to continue after qualification, and this was reported in the studies as a disincentive to prescribing. Although prescribing courses and requirements fulfilled respective national standards, a lack of specific content may have led many pharmacists to feel underprepared for their prescribing role. A UK study offered suggestions as to what should be covered in training and although some 34 distinct issues were raised, those most frequently identified were physical examination, consultation and clinical skills (46). These were cited in this review as areas which pharmacists needed better training on. A recommendation from this systematic review is therefore that there is a need for the regulatory authorities responsible for designating pharmacists as prescribers to review and enhance training requirements in patient examination, consultation and diagnostic skills. In Canada, this could include a formal structured education programme, and in the UK, a greater time allocation in a supervised patient facing setting for pharmacists to experience and learn the clinical skills relevant to prescribing. In Alberta, Canada, it has been suggested that the lack of significant advancement in the pharmacy profession is related to pharmacists' lack of confidence in their ability to step outside more traditional roles and responsibilities and promote their skill set (22) and this is where better education and training would help.

Access to patient medical records was often mentioned as critical in enabling prescribing by pharmacists. Guidelines from the Ontario college of pharmacists in Canada state that it is the pharmacist who is accountable for the personal health information collected and retained during prescribing (47). Noteworthy in the "Five Year Forward View" (48), published by the NHS, is the statement that all health professionals who prescribe should be required to keep records of a patient's care, with details of any prescription and consultation entered onto a shared patient record. In 2018 the RPS published guidelines for pharmacist prescribing (49). These included, that in the interest of delivering high quality, safe and effective patient care, all pharmacists should have appropriate access to, and be able to input into, the patient health record. These numerous recommendations concerning health records for patients, appear to be incompatible with the experiences reported by many pharmacists in this systematic review. Patients' medical records are frequently located in general practice and are generally inaccessible. Clinical record keeping is an 
integral component in good professional practice and the delivery of quality healthcare (50). Access and keeping clinical records enables coordination and continuity of care by the multidisciplinary team (which includes pharmacists) and reduces medico-legal risks and issues to patient care (50). Therefore, better access to records should be given to pharmacists who prescribe in primary care along with read/write access to patient medical records.

A UK study from 2012, examined non-medical prescribing by nearly one thousand nurses and pharmacists across a large geographic area and identified pharmacists working in primary care as prescribing least of all the included health care professionals (3). This was due to multiple factors, including difficulty in accessing and using patient records, less support from doctors and working in a role which didn't often require prescribing activity. For example, a recent study in Wales, UK, highlighted that although non-medical prescribing has been implemented across the whole of Wales; its uptake has been inconsistent, and it has not been considered across all services, particularly those in primary care (21). A Canadian study came to a similar conclusion, noting that delays in access to prescription pads or electronic prescribing were a fundamental issue that prevented prescribing in primary care (51). It could be argued that the reported lack of prescribing activity is wasteful in terms of the time and expenses incurred for training. Furthermore, the combination of logistical difficulties and training inadequacy have resulted in a failure to fully deliver the predicted improvement to patient care that non-medical prescribing in primary care was expected to achieve. Evidence from this review demonstrates that successful implementation of non-medical pharmacist prescribing requires a more coordinated approach beyond that which is immediately achievable by the pharmacy profession alone. A collaborative approach from other stakeholders is needed to overcome the barriers in the practice environment.

Pharmacist's role is the second theme in this review. Caution, due to fear of making errors when prescribing, was reported by many pharmacists. Concern of litigation, which was also identified in this review, infers that some pharmacists working in primary care believe that prescribing is inherently a higher risk activity than their established dispensing role. Medication supply, however, is already a high-risk process and can lead to both preventable 
and nonpreventable medical errors (52). One study made clear that the adoption of nonmedical prescribing by pharmacists raises a number of questions about what it means to be a professional where boundaries are changing (53). Prescribing is a task that generates uncertainty and requires professional judgement, it is a staged process rather than a single event (54). Prescribing comprises information gathering, clinical decision making, communication of prescribing decision and monitoring and review of therapy. Any step in this prescribing process can generate errors (55). A study suggested pharmacists like to work in a way that is methodical, precise and organised (56) and this may be contrary to the skills required when prescribing as this generates more uncertainty and requires more steps. Despite some recognition of secondary roles in dealing with minor ailments and providing advice (57), pharmacists are defined principally as suppliers of medicines and not prescribers. This is not to suggest that pharmacists are incapable of changing their behaviours, rather that they are more comfortable performing tasks that they feel they have previously mastered (58).

Primary care pharmacy remains dominated by community pharmacy, this sector is both a business and a profession. Many pharmacists in this review report absent or insufficient funding in order to prescribe. It is proposed that prescribing must be adequately remunerated for it to become more widely established in primary care.

Some pharmacists in this review reported satisfaction and enthusiasm to prescribe. This is identified under the sub-theme of professionalism and benefits. This work fulfilment, combined with research that confirms that the health outcomes and quality of care from non-medical prescribing is at least equivalent to that offered by doctors $(59,60)$ explains why some pharmacists report prescribing frequently. It is assumed that these pharmacists achieve positive outcomes fulfilling many of the aims of non-medical prescribing, including supporting other healthcare professionals, improving patient care, and making better use of pharmacists' skills. Reasons for this success included that for some pharmacists lack of confidence somewhat abated after prescribing began (28), some pharmacists were more suitable for this advanced role and were in a position to use their prescribing qualification promptly (29), and other pharmacists felt more integrated into the healthcare team, working closely with doctors and nurses, often working in a GP practice (38). 
Since thematic synthesis was completed for this paper, a systematic review and thematic synthesis was published in 2018 , looking at the facilitators and barriers to non-medical prescribing. (61). The nursing profession dominated the studies included in this review, however data from pharmacist NMPs was included in the analysis. The paper identified three themes: non-medical prescriber, human factors, and organisational aspects. These are similar themes to those identified in this systematic review.

\section{CONCLUSIONS}

Primary care and community pharmacy, in particular, is not an easy arena for non-medical prescribing. There are significant barriers, with escalating pharmacist workload and difficulties in fully implementing prescribing. Additionally, there can be uncertainty from pharmacists who primarily undertake dispensing and may be wary of expanding into a prescribing role. However, with an increase in demand from patients, and continued pressures on health services throughout the world, non-medical prescribing has the potential to expand. For pharmacists in primary care to fully capitalise and become part of this, better training and the removal of obstacles in the practice environment are required. This would allow the reported satisfaction and enhanced status associated with prescribing to motivate more primary care pharmacists to become prescribers and support the wider healthcare community to improve patient outcomes.

\section{Conflict of interest}

The authors declare that they have no conflict of interest to disclose.

\section{Funding}

This research received no grant from any funding agency in the public, commercial, or notfor-profit sectors.

\section{AUTHORS CONTRIBUTIONS}

TM drafted the study with all other authors revising it critically, with access to the study data. All authors had final approval of the version to be published. 


\section{References}

1. Bhanbhro S, Drennan VM, Grant R, Harris R. Assessing the contribution of prescribing in primary care by nurses and professionals allied to medicine: a systematic review of literature. BMC Health Serv Res. 2011;11(1):330.

2. Tonna AP, Stewart D, McCaig D. An international overview of some pharmacist prescribing models. J Malta Coll Pharm Pr. 2008;14:20-26.

3. Courtenay M, Carey N, Stenner K. Non medical prescribing leads views on their role and the implementation of non medical prescribing from a multi-organisational perspective. BMC Health Serv Res. 2011;11(1):142.

4. Latter S, Blenkinsopp A, Smith A, Chapman S, Tinelli M, Gerard K, et al. Evaluation of nurse and pharmacist independent prescribing. 2011;

5. Latter S, Smith A, Blenkinsopp A, Nicholls P, Little $P$, Chapman S. Are nurse and pharmacist independent prescribers making clinically appropriate prescribing decisions? An analysis of consultations. J Health Serv Res Policy. 2012;17(3):149-156.

6. Mansell K, Bootsman N, Kuntz A, Taylor J. Evaluating pharmacist prescribing for minor ailments. Int J Pharm Pract. 2015;23(2):95-101.

7. Tinelli M, Blenkinsopp A, Latter S, Smith A, Chapman SR. Survey of patients' experiences and perceptions of care provided by nurse and pharmacist independent prescribers in primary care. Health Expect. 2015;18(5):1241-1255.

8. Watterson A, Turner F, Coull A, Murray I. An Evaluation of the Expansion of Nurse Prescribing in Scotland. : 180.

9. Emmerton L, Marriott J, Bessell T, Nissen L, Dean L. Pharmacists and prescribing rights: review of international developments. J Pharm Pharm Sci. 2005;8(2):217-225.

10. Ball J, infirmières $C$ international des. Implementing nurse prescribing: an updated review of current practice internationally. International Council of Nurses; 2009.

11. Kroezen $M$, van Dijk L, Groenewegen PP, Francke AL. Nurse prescribing of medicines in Western European and Anglo-Saxon countries: a systematic review of the literature. BMC Health Serv Res. 2011;11(1):127.

12. Auta A, Strickland-Hodge B, Maz J. Stakeholders' views on granting prescribing authority to pharmacists in Nigeria: a qualitative study. Int J Clin Pharm. 2016;38(4):960-7.

13. Mwawaka JS. Impact of Independent Pharmacist Prescribing on the Future of Pharmacy. Innov Pharm. 2016;7(4).

14. Yariv H. The case of pharmacist prescribing policy in Israel. Isr J Health Policy Res. 2015;4(1):49.

15. Hobson RJ, Sewell GJ. Supplementary prescribing by pharmacists in England. Am J Health Syst Pharm. 2006;63(3):244-253. 
16. Pharmacy AC of C, Hammond RW, Schwartz AH, Campbell MJ, Remington TL, Chuck S, et al. Collaborative drug therapy management by pharmacists - 2003. Pharmacother J Hum Pharmacol Drug Ther. 2003;23(9):1210-1225.

17. Jones M, Bennett J, Lucas B, Miller D, Gray R. Mental health nurse supplementary prescribing: experiences of mental health nurses, psychiatrists and patients. J Adv Nurs. 2007;59(5):488496.

18. Cope LC, Abuzour AS, Tully MP. Nonmedical prescribing: where are we now? Ther Adv Drug Saf. 2016;7(4):165-72.

19. Stewart D, MacLure K, George J. Educating nonmedical prescribers. Br J Clin Pharmacol. 2012;74(4):662-667.

20. Timothy Mills. GPhC. 2017.

21. Courtenay M, Khanfer R, Harries-Huntly G, Deslandes R, Gillespie D, Hodson K, et al. Overview of the uptake and implementation of non-medical prescribing in Wales: a national survey. BMJ Open. 2017;7(9):e015313.

22. Rosenthal MM, Houle SK, Eberhart G, Tsuyuki RT. Prescribing by pharmacists in Alberta and its relation to culture and personality traits. Res Soc Adm Pharm. 2015;11(3):401-411.

23. Moher D, Liberati A, Tetzlaff J, Altman DG. Preferred reporting items for systematic reviews and meta-analyses: the PRISMA statement. Ann Intern Med. 2009;151(4):264-269.

24. Tong A, Flemming K, McInnes E, Oliver S, Craig J. Enhancing transparency in reporting the synthesis of qualitative research: ENTREQ. BMC Med Res Methodol. 2012 Nov 27;12(1):181.

25. casp. CASP Checklists [Internet]. CASP - Critical Appraisal Skills Programme. [cited 2019 June 10]. Available from: https://casp-uk.net/casp-tools-checklists/

26. Thomas J, Harden A. Methods for the thematic synthesis of qualitative research in systematic reviews. BMC Med Res Methodol. 2008;8(1):45.

27. Bowskill D, Meade O, Lymn JS. Use and evaluation of a mentoring scheme to promote integration of non-medical prescribing in a clinical context. BMC Med Educ. 2014;14(1):177.

28. Charrois T, Rosenthal M, Tsuyuki RT. Stories from the Trenches: Experiences of Alberta Pharmacists in Obtaining Additional Prescribing Authority. Can Pharm J Rev Pharm Can. 2012;145(1):30-4.

29. Dawoud D, Griffiths P, Maben J, Goodyer L, Greene R. Pharmacist supplementary prescribing: A step toward more independence? Res Soc Adm Pharm. 2011;7(3):246-256.

30. George J, Pfleger D, McCaig D, Bond C, Stewart D. Independent prescribing by pharmacists: a study of the awareness, views and attitudes of Scottish community pharmacists. Pharm World Sci. 2006;28(2):45-53.

31. Hoti K, Sunderland B, Hughes J, Parsons R. An evaluation of Australian pharmacist's attitudes on expanding their prescribing role. Pharm World Sci. 2010;32(5):610-621. 
32. Hughes CA, Makowsky M, Sadowski CA, Schindel TJ, Yuksel N, Guirguis LM. What prescribing means to pharmacists: a qualitative exploration of practising pharmacists in A lberta. Int J Pharm Pract. 2014;22(4):283-291.

33. Maddox C, Halsall D, Hall J, Tully MP. Factors influencing nurse and pharmacist willingness to take or not take responsibility for non-medical prescribing. Res Soc Adm Pharm.

2016;12(1):41-55.

34. Makowsky MJ, Guirguis LM, Hughes CA, Sadowski CA, Yuksel N. Factors influencing pharmacists' adoption of prescribing: qualitative application of the diffusion of innovations theory. Implement Sci. 2013;8(1):109.

35. McCann L, Haughey S, Parsons C, Lloyd F, Crealey G, Gormley GJ, et al. Pharmacist prescribing in Northern Ireland: a quantitative assessment. Int J Clin Pharm. 2011;33(5):824.

36. McIntosh T, Munro K, McLay J, Stewart D. A cross sectional survey of the views of newly registered pharmacists in Great Britain on their potential prescribing role: a cautious approach: Short report. Br J Clin Pharmacol. 2012 Apr;73(4):656-60.

37. McIntosh T, Stewart D. A qualitative study of UK pharmacy pre-registration graduates' views and reflections on pharmacist prescribing: Qualitative study: UK pharmacy pre-reg graduates. Int J Pharm Pract. 2016 Apr;24(2):139-41.

38. Stewart DC, George J, Bond CM, Diack HL, McCaig DJ, Cunningham S. Views of pharmacist prescribers, doctors and patients on pharmacist prescribing implementation. Int J Pharm Pract. 2009;17(2):89-94.

39. Tully MP, Latif $S$, Cantrill JA, Parker D. Pharmacists' changing views of their supplementary prescribing authority. Pharm World Sci. 2007;29(6):628-634.

40. Weiss MC, Sutton J. The changing nature of prescribing: pharmacists as prescribers and challenges to medical dominance. Sociol Health IIIn. 2009;31(3):406-421.

41. Pharmacist independent prescriber | General Pharmaceutical Council [Internet]. [cited 2019 Aug 11]. Available from: https://www.pharmacyregulation.org/education/pharmacistindependent-prescriber

42. Law MR, Ma T, Fisher J, Sketris IS. Independent pharmacist prescribing in Canada. Can Pharm J CPJ. 2012 Jan;145(1):17-23.e1.

43. Yuksel N, Eberhart G, Bungard TJ. Prescribing by pharmacists in Alberta [Internet]. American Journal of Health-System Pharmacy. 2008 [cited 2019 Aug 11]. Available from: https://link.galegroup.com/apps/doc/A192000647/AONE?sid=Ims

44. Pharmacist prescribing by 2020? What you need to know [Internet]. AJP. 2018 [cited 2019 Aug 18]. Available from: https://ajp.com.au/features/professional/pharmacist-prescribing-by-2020what-you-need-to-know/

45. Australia TPG of. Home [Internet]. [cited 2019 Aug 18]. Available from: https://www.guild.org.au 
46. Cooper RJ, Anderson C, Avery T, Bissell P, Guillaume L, Hutchinson A, et al. Nurse and pharmacist supplementary prescribing in the UK-A thematic review of the literature. Health Policy. 2007 2008;85(3):277-92.

47. Documentation Guidelines - OCPInfo.com [Internet]. [cited 2019 Aug 13]. Available from: http://www.ocpinfo.com/regulations-standards/practice-policies-guidelines/documentationguidelines/

48. NHS England, Health Education England, NHS Trust Development Authority CQC. Five Year Forward View [Internet]. 2014 [cited 2019 May 1]. Available from:

http://www.england.nhs.uk/wp-content/uploads/2014/10/5yfv-web.pdf

49. Royal Pharmaceutical S. Pharmacist Independent Prescribers [Internet]. Royal Pharmaceutical Society; 2018 [cited 2019 Jul 10]. Available from:

https://www.rpharms.com/Portals/0/RPS\%20document\%20library/Open\%20access/Policy/GB \%20Prescriber\%20Policy\%20-FINAL.pdf?ver=2018-08-07-152908-900

50. Mathioudakis A, Rousalova I, Gagnat AA, Saad N, Hardavella G. How to keep good clinical records. Breathe. 2016 Dec;12(4):369-73.

51. Guirguis LM, Makowsky M, Hughes C, Sadowski C, Yüksel N. Exploring pharmacists' adoption of prescribing in Alberta. Can Pharm J CPJRPC. 2012 Aug;145(4):S10.

52. Gorbach C, Blanton L, Lukawski BA, Varkey AC, Pitman EP, Garey KW. Frequency of and risk factors for medication errors by pharmacists during order verification in a tertiary care medical center. Am J Health Syst Pharm. 2015;72(17):1471-1474.

53. Hughes $\mathrm{CM}, \mathrm{McCann} \mathrm{S}$. Perceived interprofessional barriers between community pharmacists and general practitioners: a qualitative assessment. Br J Gen Pract. 2003 Aug;53(493):600-6.

54. Anyika, Emmanuel, Okeke, Joy I. Prescribing errors and uncertainity: coping strategies of physicians and pharmacists in a tertiary university hospital. J Hosp Adm [Internet]. $2016 \mathrm{Apr}$ 5;5(No. 3). Available from: http://dx.doi.org/10.5430/jha.v5b3p81

55. Velo GP, Minuz P. Medication errors: prescribing faults and prescription errors. Br J Clin Pharmacol. 2009 Jun;67(6):624-8.

56. Elvey R, Hassell K, Hall J. Who do you think you are? Pharmacists' perceptions of their professional identity: Professional identity in pharmacy. Int J Pharm Pract. 2013 Oct;21(5):32232.

57. Gidman W, Cowley J. A qualitative exploration of opinions on the community pharmacists' role amongst the general public in S cotland. Int J Pharm Pract. 2013;21(5):288-296.

58. Lowenthal W. Myers-Briggs Type Inventory preferences of pharmacy students and practitioners. Eval Health Prof. 1994;17(1):22-42.

59. substitution of doctors by nurses in primary care - Google Scholar [Internet]. [cited 2018 Oct 18]. Available from:

https://scholar.google.co.uk/scholar?hl=en\&as_sdt=0\%2C5\&q=substitution+of+doctors+by+nu rses+in+primary+care\&btnG $=$ 
60. Nurse practitioners as an underutilized resource for health reform: evidence-based demonstrations of cost-effectiveness. - PubMed - NCBI [Internet]. [cited 2018 Oct 18]. Available from: https://www.ncbi.nlm.nih.gov/pubmed/20409261

61. Graham-Clarke E, Rushton A, Noblet T, Marriott J. Facilitators and barriers to non-medical prescribing - A systematic review and thematic synthesis. PLoS ONE. 2018 Jan 1;13(4):e0196471.

S1 Appendix. ENTREQ checklist 


\begin{tabular}{|c|c|c|c|}
\hline No & Item & Guide and description & Page no. \\
\hline 1 & Aim & State the research question the synthesis addresses. & 5 \\
\hline 2 & $\begin{array}{l}\text { Synthesis } \\
\text { methodology }\end{array}$ & $\begin{array}{l}\text { Identify the synthesis methodology or theoretical } \\
\text { framework which underpins the synthesis, and describe } \\
\text { the rationale for choice of methodology (e.g. meta- } \\
\text { ethnography, thematic synthesis, critical interpretive } \\
\text { synthesis, grounded theory synthesis, realist synthesis, } \\
\text { meta-aggregation, meta-study, framework synthesis). }\end{array}$ & 7 \\
\hline 3 & $\begin{array}{l}\text { Approach to } \\
\text { searching }\end{array}$ & $\begin{array}{l}\text { Indicate whether the search was pre-planned } \\
\text { (comprehensive search strategies to seek all available } \\
\text { studies) or iterative (to seek all available concepts until } \\
\text { they theoretical saturation is achieved). }\end{array}$ & 5 \\
\hline 4 & $\begin{array}{l}\text { Inclusion } \\
\text { criteria }\end{array}$ & $\begin{array}{l}\text { Specify the inclusion/exclusion criteria (e.g. in terms of } \\
\text { population, language, year limits, type of publication, } \\
\text { study type). }\end{array}$ & 6 \\
\hline 5 & Data sources & $\begin{array}{l}\text { Describe the information sources used (e.g. electronic } \\
\text { databases (MEDLINE, EMBASE, CINAHL, psycINFO, Econlit), } \\
\text { grey literature databases (digital thesis, policy reports), } \\
\text { relevant organisational websites, experts, information } \\
\text { specialists, generic web searches (Google Scholar) hand } \\
\text { searching, reference lists) and when the searches } \\
\text { conducted; provide the rationale for using the data } \\
\text { sources. }\end{array}$ & 5 \\
\hline 6 & $\begin{array}{l}\text { Electronic } \\
\text { Search } \\
\text { strategy }\end{array}$ & $\begin{array}{l}\text { Describe the literature search (e.g. provide electronic } \\
\text { search strategies with population terms, clinical or health } \\
\text { topic terms, experiential or social phenomena related } \\
\text { terms, filters for qualitative research, and search limits). }\end{array}$ & 5 \\
\hline 7 & $\begin{array}{l}\text { Study } \\
\text { screening } \\
\text { methods }\end{array}$ & $\begin{array}{l}\text { Describe the process of study screening and sifting (e.g. } \\
\text { title, abstract and full text review, number of independent } \\
\text { reviewers who screened studies). }\end{array}$ & 5 \\
\hline 8 & $\begin{array}{l}\text { Study } \\
\text { characteristics }\end{array}$ & $\begin{array}{l}\text { Present the characteristics of the included studies (e.g. } \\
\text { year of publication, country, population, number of } \\
\text { participants, data collection, methodology, analysis, } \\
\text { research questions). }\end{array}$ & Table 1 \\
\hline 9 & $\begin{array}{l}\text { Study } \\
\text { selection }\end{array}$ & $\begin{array}{l}\text { Identify the number of studies screened and provide } \\
\text { reasons for study exclusion (e.g. for comprehensive } \\
\text { searching, provide numbers of studies screened and } \\
\text { reasons for exclusion indicated in a figure/flowchart; for } \\
\text { iterative searching describe reasons for study exclusion and } \\
\text { inclusion based on modifications the research question } \\
\text { and/or contribution to theory development). }\end{array}$ & 15 \\
\hline 10 & $\begin{array}{l}\text { Rationale for } \\
\text { appraisal }\end{array}$ & $\begin{array}{l}\text { Describe the rationale and approach used to appraise the } \\
\text { included studies or selected findings (e.g. assessment of } \\
\text { conduct (validity and robustness), assessment of reporting } \\
\text { (transparency), assessment of content and utility of the } \\
\text { findings). }\end{array}$ & Table 2 \\
\hline 11 & $\begin{array}{l}\text { Appraisal } \\
\text { items }\end{array}$ & $\begin{array}{l}\text { State the tools, frameworks and criteria used to appraise } \\
\text { the studies or selected findings (e.g. Existing tools: CASP, } \\
\text { QARI, COREQ, Mays and Pope [25]; reviewer developed }\end{array}$ & 6,7 \\
\hline
\end{tabular}




\begin{tabular}{|c|c|c|c|}
\hline & & $\begin{array}{l}\text { tools; describe the domains assessed: research team, study } \\
\text { design, data analysis and interpretations, reporting). }\end{array}$ & \\
\hline 12 & $\begin{array}{l}\text { Appraisal } \\
\text { process }\end{array}$ & $\begin{array}{l}\text { Indicate whether the appraisal was conducted } \\
\text { independently by more than one reviewer and if } \\
\text { consensus was required. }\end{array}$ & 5 \\
\hline 13 & $\begin{array}{l}\text { Appraisal } \\
\text { results }\end{array}$ & $\begin{array}{l}\text { Present results of the quality assessment and indicate } \\
\text { which articles, if any, were weighted/excluded based on } \\
\text { the assessment and give the rationale. }\end{array}$ & Table 2 \\
\hline 14 & $\begin{array}{l}\text { Data } \\
\text { extraction }\end{array}$ & $\begin{array}{l}\text { Indicate which sections of the primary studies were } \\
\text { analysed and how were the data extracted from the } \\
\text { primary studies? (e.g. all text under the headings "results } \\
\text { /conclusions" were extracted electronically and entered } \\
\text { into a computer software).. }\end{array}$ & 7 \\
\hline 15 & Software & State the computer software used, if any. & 7 \\
\hline 16 & $\begin{array}{l}\text { Number of } \\
\text { reviewers }\end{array}$ & Identify who was involved in coding and analysis & 7 \\
\hline 17 & Coding & $\begin{array}{l}\text { Describe the process for coding of data (e.g. line by line } \\
\text { coding to search for concepts). }\end{array}$ & 7 \\
\hline 18 & $\begin{array}{l}\text { Study } \\
\text { comparison }\end{array}$ & $\begin{array}{l}\text { Describe how were comparisons made within and across } \\
\text { studies (e.g. subsequent studies were coded into pre- } \\
\text { existing concepts, and new concepts were created when } \\
\text { deemed necessary). }\end{array}$ & 7 \\
\hline 19 & $\begin{array}{l}\text { Derivation of } \\
\text { themes }\end{array}$ & $\begin{array}{l}\text { Explain whether the process of deriving the themes or } \\
\text { constructs was inductive or deductive. }\end{array}$ & 7 \\
\hline 20 & Quotations & $\begin{array}{l}\text { Provide quotations from the primary studies to illustrate } \\
\text { themes/constructs, and identify whether the quotations } \\
\text { were participant quotations of the author's interpretation. }\end{array}$ & $17-21$ \\
\hline 21 & $\begin{array}{l}\text { Synthesis } \\
\text { output }\end{array}$ & $\begin{array}{l}\text { Present rich, compelling and useful results that go beyond } \\
\text { a summary of the primary studies (e.g. new interpretation, } \\
\text { models of evidence, conceptual models, analytical } \\
\text { framework, development of a new theory or construct). }\end{array}$ & $17-21$ \\
\hline
\end{tabular}

\section{S2 Appendix. ENTREQ checklist}




\section{PRISMA 2009 Checklist}

\begin{tabular}{|c|c|c|c|}
\hline Section/topic & $\#$ & Checklist item & $\begin{array}{l}\text { Reported } \\
\text { on page \# }\end{array}$ \\
\hline \multicolumn{4}{|l|}{ TITLE } \\
\hline Title & 1 & Identify the report as a systematic review, meta-analysis, or both. & 1 \\
\hline \multicolumn{4}{|l|}{ ABSTRACT } \\
\hline Structured summary & 2 & $\begin{array}{l}\text { Provide a structured summary including, as applicable: background; objectives; data sources; study eligibility criteria, participants, } \\
\text { and interventions; study appraisal and synthesis methods; results; limitations; conclusions and implications of key findings. }\end{array}$ & $1-2$ \\
\hline \multicolumn{4}{|l|}{ INTRODUCTION } \\
\hline Rationale & 3 & Describe the rationale for the review in the context of what is already known. & $3-4$ \\
\hline Objectives & 4 & $\begin{array}{l}\text { Provide an explicit statement of questions being addressed with reference to participants, interventions, comparisons, outcomes, } \\
\text { and study design (PICOS). }\end{array}$ & $5-7$ \\
\hline \multicolumn{4}{|l|}{ METHODS } \\
\hline Protocol and registration & 5 & $\begin{array}{l}\text { Indicate if a review protocol exists, if and where it can be accessed (e.g., Web address), and, if available, provide registration } \\
\text { information including registration number. }\end{array}$ & 7 \\
\hline Eligibility criteria & 6 & $\begin{array}{l}\text { Specify study characteristics (e.g., PICOS, length of follow-up) and report characteristics (e.g., years considered, language, } \\
\text { publication status) used as criteria for eligibility, giving rationale. }\end{array}$ & 6 \\
\hline Information sources & 7 & $\begin{array}{l}\text { Describe all information sources (e.g., databases with dates of coverage, contact with study authors to identify additional studies) } \\
\text { in the search and date last searched. }\end{array}$ & 5 \\
\hline Search & 8 & Present full electronic search strategy for at least one database, including any limits used, such that it could be repeated. & 6 \\
\hline Study selection & 9 & $\begin{array}{l}\text { State the process for selecting studies (i.e., screening, eligibility, included in systematic review, and, if applicable, included in the } \\
\text { meta-analysis). }\end{array}$ & 6 \\
\hline Data collection process & 10 & $\begin{array}{l}\text { Describe method of data extraction from reports (e.g., piloted forms, independently, in duplicate) and any processes for obtaining } \\
\text { and confirming data from investigators. }\end{array}$ & $6-7$ \\
\hline Data items & 11 & $\begin{array}{l}\text { List and define all variables for which data were sought (e.g., PICOS, funding sources) and any assumptions and simplifications } \\
\text { made. }\end{array}$ & 26 \\
\hline Risk of bias in individual studies & 12 & $\begin{array}{l}\text { Describe methods used for assessing risk of bias of individual studies (including specification of whether this was done at the } \\
\text { study or outcome level), and how this information is to be used in any data synthesis. }\end{array}$ & Table 2 \\
\hline Summary measures & 13 & State the principal summary measures (e.g., risk ratio, difference in means). & $15-16$ \\
\hline
\end{tabular}




\section{PRISMA 2009 Checklist}

\begin{tabular}{|c|c|c|c|}
\hline Synthesis of results & 14 & $\begin{array}{l}\text { Describe the methods of handling data and combining results of studies, if done, including measures of consistency }\left(e . g ., I^{2}\right) \text { for } \\
\text { each meta-analysis. }\end{array}$ & $15-16$ \\
\hline Section/topic & $\#$ & Checklist item & $\begin{array}{l}\text { Reported } \\
\text { on page \# }\end{array}$ \\
\hline Risk of bias across studies & 15 & $\begin{array}{l}\text { Specify any assessment of risk of bias that may affect the cumulative evidence (e.g., publication bias, selective reporting within } \\
\text { studies). }\end{array}$ & Table 2 \\
\hline Additional analyses & 16 & $\begin{array}{l}\text { Describe methods of additional analyses (e.g., sensitivity or subgroup analyses, meta-regression), if done, indicating which were } \\
\text { pre-specified. }\end{array}$ & $\mathrm{n} / \mathrm{a}$ \\
\hline \multicolumn{4}{|l|}{ RESULTS } \\
\hline Study selection & 17 & $\begin{array}{l}\text { Give numbers of studies screened, assessed for eligibility, and included in the review, with reasons for exclusions at each stage, } \\
\text { ideally with a flow diagram. }\end{array}$ & 6,15 \\
\hline Study characteristics & 18 & $\begin{array}{l}\text { For each study, present characteristics for which data were extracted (e.g., study size, PICOS, follow-up period) and provide the } \\
\text { citations. }\end{array}$ & $\begin{array}{l}\text { Table } 1 \\
\text { Table } 2\end{array}$ \\
\hline Risk of bias within studies & 19 & Present data on risk of bias of each study and, if available, any outcome level assessment. & 16 \\
\hline Results of individual studies & 20 & $\begin{array}{l}\text { For all outcomes considered (benefits or harms), present, for each study: (a) simple summary data for each intervention group (b) } \\
\text { effect estimates and confidence intervals, ideally with a forest plot. }\end{array}$ & $\mathrm{n} / \mathrm{a}$ \\
\hline Synthesis of results & 21 & Present results of each meta-analysis done, including confidence intervals and measures of consistency. & $\begin{array}{l}\text { Table } 1 \\
\text { Table } 2\end{array}$ \\
\hline Risk of bias across studies & 22 & Present results of any assessment of risk of bias across studies. & 6 \\
\hline Additional analysis & 23 & Give results of additional analyses, if done (e.g., sensitivity or subgroup analyses, meta-regression [see Item 16]). & $\mathrm{n} / \mathrm{a}$ \\
\hline \multicolumn{4}{|l|}{ DISCUSSION } \\
\hline Summary of evidence & 24 & $\begin{array}{l}\text { Summarize the main findings including the strength of evidence for each main outcome; consider their relevance to key groups } \\
\text { (e.g., healthcare providers, users, and policy makers). }\end{array}$ & $21-25$ \\
\hline Limitations & 25 & $\begin{array}{l}\text { Discuss limitations at study and outcome level (e.g., risk of bias), and at review-level (e.g., incomplete retrieval of identified } \\
\text { research, reporting bias). }\end{array}$ & $21-22$ \\
\hline Conclusions & 26 & Provide a general interpretation of the results in the context of other evidence, and implications for future research. & 25 \\
\hline \multicolumn{4}{|l|}{ FUNDING } \\
\hline Funding & 27 & $\begin{array}{l}\text { Describe sources of funding for the systematic review and other support (e.g., supply of data); role of funders for the } \\
\text { systematic review. }\end{array}$ & 26 \\
\hline
\end{tabular}




\section{PRISMA 2009 Checklist}

